Review

\title{
Leaching of ilmenite to produce titanium based materials: a review
}

\author{
Charitha Thambiliyagodage ${ }^{1} \cdot$ Ramanee Wijesekera $^{2} \cdot$ Martin G. Bakker $^{3}$
}

Received: 28 August 2021 / Accepted: 29 November 2021

Published online: 09 December 2021

(c) The Author(s) 2021 OPEN

\begin{abstract}
Naturally available ilmenite mineral is being used as a starting material to produce titanium based products that have wide applications. Transformation of ilmenite to different titanium based materials by strong and weak acid, and base digestion, is discussed. Effects of temperature, concentration of acid/base, reaction time on dissolution of ilmenite are extensively reviewed. Characterization of the starting materials, intermediates and the products by $\mathrm{x}$-ray diffraction, thermogravimetry, brunauer-emmett-teller surface area analysis, and scanning electron microscopy are presented. Further, advantages and disadvantages associated with the digestion methods are discussed.
\end{abstract}

Keywords Ilmenite $\cdot$ Acid $\cdot$ Base $\cdot$ Digestion $\cdot \mathrm{TiO}_{2}$

\section{Introduction}

$\mathrm{TiO}_{2}$ based materials have attracted significant interest in many fields of applications owing to their unique characteristic features. $\mathrm{TiO}_{2}$ is well known for its photocatalytic activity including water splitting and degradation of organic molecules in particular. $\mathrm{H}_{2}$ is considered to be a future clean fuel due to the depletion of fossil fuels. It is easily generated by water splitting catalyzed by $\mathrm{TiO}_{2}$ based catalysts [1-3]. Organic molecules such as textile dyes [4-6], pesticides [7, 8], pharmaceuticals [9-11] present as pollutants mainly in wastewater, are degraded by $\mathrm{TiO}_{2}$ based catalysts in the presence of UV and/or visible light. Further, such photocatalysis has been shown to be effective in antimicrobial activities [12-14]. Briefly, the photocatalytic activity of $\mathrm{TiO}_{2}$ could be explained as; upon exposure to UV light a photogenerated electron excites to the conduction band from the valence band leaving a hole in the valence band. The photocatalytic activity is caused by the photogenerated electrons and holes. $\mathrm{TiO}_{2}$ is promising in photovoltaic cells $[15,16]$ as electrons that are generated when the photosensitizer absorbs light are handed over to the conduction band of $\mathrm{TiO}_{2}$. These diffuse towards the counter electrode through the transparent conducting oxide electrode to complete the circuit [17]. Further, $\mathrm{TiO}_{2}$ is used as the anode material in Lithium ion batteries in electric vehicles, mobile electronics etc. due to its high working voltage that ensures a stable operation $[18,19] . \mathrm{TiO}_{2}$ is used as a white pigment in paints, coatings, plastics and inks due to its unique light scattering ability especially of the Rutile phase which has the highest refractive index. Further, pigmentary $\mathrm{TiO}_{2}$ is inert, non-toxic, thermodynamically stable and inexpensive [20]. Moreover, $\mathrm{TiO}_{2}$ has been modified by doping metals [21], non-metals [22], and coupling with metal oxides [23] and non-metal oxides [24] to improve its activity especially in the visible region. Hence, the research world has focused extensively on applications of $\mathrm{TiO}_{2}$ based materials in energy generation and environmental cleanup. In view of the vast potential that $\mathrm{TiO}_{2}$ has, it is important to

$\triangle$ Charitha Thambiliyagodage, charitha.t@sliit.lk | ${ }^{1}$ Faculty of Humanities and Sciences, Sri Lanka Institute of Information Technology, New Kandy Road, Malabe, Sri Lanka. ${ }^{2}$ Department of Chemistry, University of Colombo, Colombo, Sri Lanka. ${ }^{3}$ Department of Chemistry and Biochemistry, The University of Alabama, Tuscaloosa, AL 35387-0336, USA. 
explore other sources of $\mathrm{TiO}_{2}$ as an alternative to the expensive process of synthesizing it. Table 1 summarizes some of the applications of $\mathrm{TiO}_{2}$ described above.

With such wide applicability of $\mathrm{TiO}_{2}$, researches came across with different synthesis methods to synthesize $\mathrm{TiO}_{2}$ using different chemical precursors. Electrophoretic deposition [25], spray pyrolysis [26], sonochemical [27] and microwave-assisted methods [28], hydro/solvothermal methods [28]and sol-gel methods[29] are used to synthesize Ti based materials. Those methods use precursors including Titanium isopropoxide [30], titanium butoxide [31], titanium oxyacetylacetonate [32], titanium tetrachloride [33] which are expensive. Further, some applications especially synthesis of visible light sensitive $\mathrm{TiO}_{2}$ require more chemicals including transition metal precursors, N/C/S/F/l precursors, graphene based materials and precursors require to synthesize metal oxides [34]. At the same time, Ti based materials are widely used. Therefore, it is vital to use naturally available Ti sources to produce Ti precursors for various synthesis. Meanwhile, ilmenite the key material discussed in this review contains iron as the main impurity along with other impurities including $\mathrm{SiO}_{2}, \mathrm{MnO}$ etc. as discussed in Sect. 2. Presence of such impurities also contribute to enhance the activity of Ti based materials especially in photocatalysis. Hence, it is significant to study about ilmenite which is the main natural source of $\mathrm{TiO}_{2}$ in the world.

\section{Geological distribution of Titanium based minerals}

Titanium is the ninth most abundant element in the Earth's crust and it is present mainly in the form of ilmenite (40-80\% $\left.\mathrm{TiO}_{2}\right)$, rutile $\left(\sim 95 \% \mathrm{TiO}_{2}\right)$, anatase $\left(>95 \% \mathrm{TiO}_{2}\right)$, and leucoxene $\left(>65 \% \mathrm{TiO}_{2}\right)$ [35-38]. Major ilmenite deposits of the world are found in countries such as Australia (eastern and western coast), South Africa (Richards bay), America (eastern coat), India (Kerala), Brazil (eastern and southern coast). In addition, ilmenite is present in other countries such as Norway, Ukraine, Vietnam, and Sri Lanka comparatively in smaller quantities. Worldwide mine production of titanium minerals in 2020 is shown in Fig. 1. Although the main constituent of these deposits is ilmenite, they also include many metallic and non-metallic compounds such as $\mathrm{TiO}_{2}, \mathrm{FeO}, \mathrm{Fe}_{2} \mathrm{O}_{3}, \mathrm{Na}_{2} \mathrm{O}, \mathrm{SiO}_{2}, \mathrm{Al}_{2} \mathrm{O}_{3}, \mathrm{ZrO}_{2}, \mathrm{Cr}_{2} \mathrm{O}_{3}, \mathrm{MnO}, \mathrm{CaO}, \mathrm{MgO}, \mathrm{SnO}_{2}, \mathrm{~K}_{2} \mathrm{O}_{2} \mathrm{~V}_{2} \mathrm{O}_{5}, \mathrm{P}_{2} \mathrm{O}_{5}$, $\mathrm{SO}_{3}$ as revealed by XRF analysis. Table 2 summarizes some ilmenite available locations along with the composition. It is evident that the composition of ilmenite deposits presents in different areas vary qualitatively and quantitatively and more interestingly a heterogeneous composition is found even within the same area in a country. Deposit types of $\mathrm{Ti}$ based minerals that occur in the world are; magmatic deposits in igneous and related rocks with ilmenite as the primary ore mineral, metamorphic deposits with rutile as the primary ore mineral, rutile in hydrothermal porphyry deposits, and heavy mineral concentrations in unconsolidated and lithified sand deposits that may include rutile, ilmenite and leucoxene [39]. Ilmenite, the most dominant titanium source is found in sea beaches and hard rock deposits while rutile, the most titanium rich mineral is present mainly in coastal areas. These available titanium sources should be subjected to appropriate treatment methods in order to be used effectively in various titanium based industries.

In this context synthesizing titanium based materials is of great importance. Titanium based materials could be synthesized by using the existing titanium sources in the market such as titanium isopropoxide, titanium chloride, etc. However, as described above ilmenite is distributed in many locations and could be used to produce different $\mathrm{Ti}$ and Fe based products. It is economically beneficial to add value to the ilmenite mineral because large scale industries utilize ilmenite as the raw material for products use in environmental remediation, energy production, synthesis of pigments, etc. This review provides a comprehensive and comparative account of the main analytical methods used to produce different titanium based materials from natural ilmenite. The main extracting methods

Table 1 Applications of $\mathrm{TiO}_{2}$

\begin{tabular}{lc}
\hline Application & References \\
\hline $\mathrm{H}_{2}$ production via water splitting & {$[1-3]$} \\
Textile dye degradation & {$[4-6]$} \\
Pesticide degradation & {$[7,8]$} \\
Pharmaceutical degradation & {$[9-11]$} \\
Antimicrobial activity & {$[12-14]$} \\
Photovoltaic cells & {$[15,16]$} \\
Lithium ion batteries & {$[18,19]$} \\
White pigment & {$[20]$} \\
\hline
\end{tabular}


Mine production of titanium minerals worldwide in 2020 , by country (in 1,000 metric tons of titanium dioxide content)

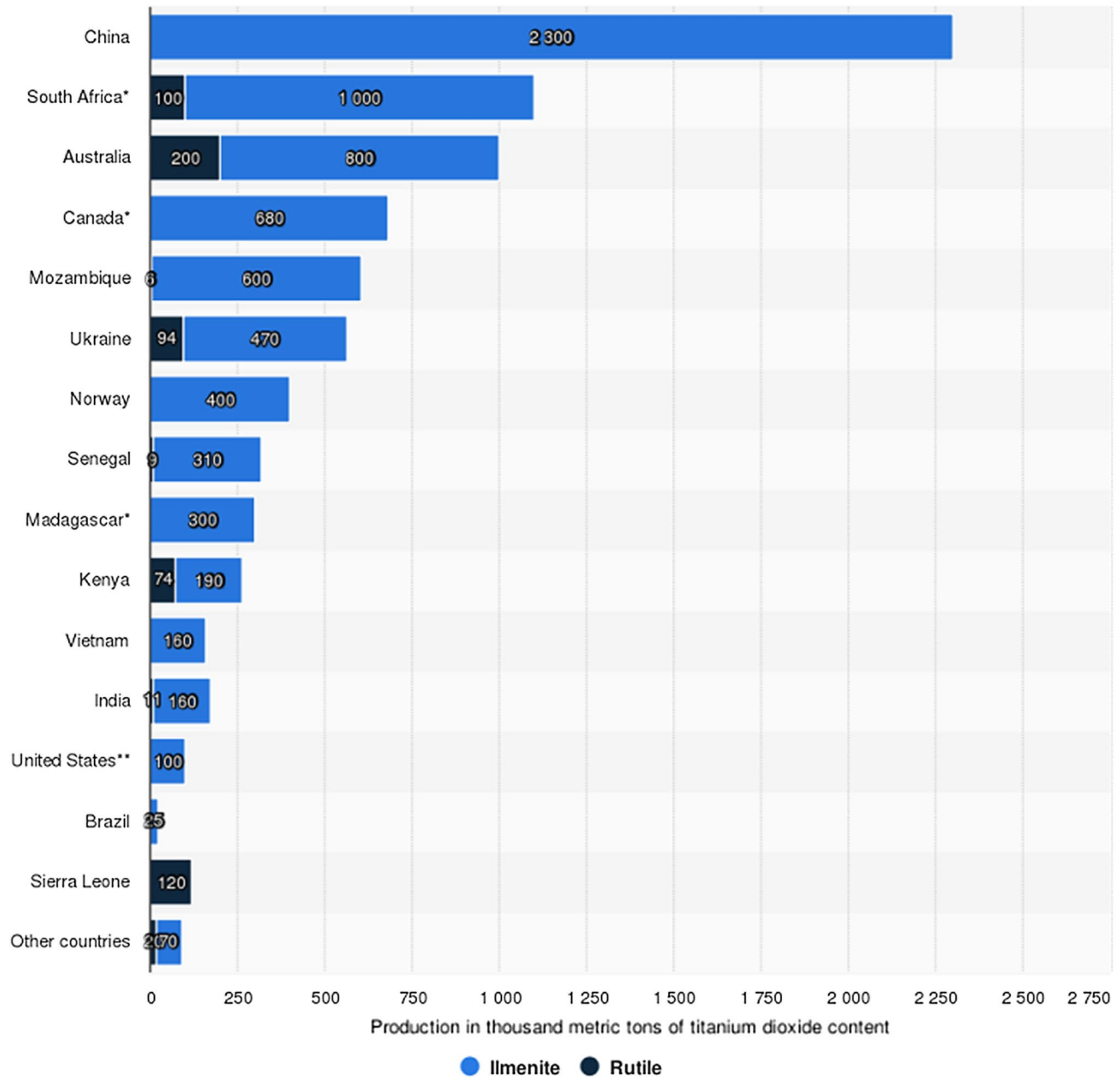

Fig. 1 Worldwide mine production of titanium minerals in 2020. (adapted from Ref. [40])

discussed in this review are acid and alkaline digestion, and hydrothermal synthesis. Ti based materials of different size, shape and composition synthesized via the above methods or a combination of these methods are reported. Further, the advantages and the disadvantages associated with each method are discussed. 
Table 2 Chemical composition of ilmenite sand collected from various locations

\begin{tabular}{|c|c|c|c|c|c|c|c|}
\hline Country & Region & Weight $\% \mathrm{TiO}_{2}$ & $\begin{array}{l}\text { Weight \% } \\
\text { FeO }\end{array}$ & $\begin{array}{l}\text { Weight \% } \\
\mathrm{Fe}_{2} \mathrm{O}_{3}\end{array}$ & $\begin{array}{l}\text { Weight \% } \\
\text { Total Fe }\end{array}$ & $\begin{array}{l}\text { Weight } \\
\% \\
\text { Other constituents }\end{array}$ & References \\
\hline \multirow[t]{3}{*}{ Egypt } & Abu Ghalaga & 41.10 & 24.40 & 28.60 & 39.01 & $\begin{array}{l}\mathrm{SiO}_{2}-2.43 \\
\mathrm{Al}_{2} \mathrm{O}_{3}-0.63 \\
\mathrm{Cr}_{2} \mathrm{O}_{3}-0.36 \\
\mathrm{MnO}-0.36 \\
\mathrm{CaO}-0.15 \\
\mathrm{MgO}-0.64 \\
\mathrm{P}_{2} \mathrm{O}_{5}-0.02 \\
\mathrm{~V}_{2} \mathrm{O}_{5}-0.40 \\
\mathrm{SO}_{3}-0.11 \\
\mathrm{CO}_{2}-0.65 \\
\text { Moisture-0.15 }\end{array}$ & [41] \\
\hline & & 40.91 & - & 51.90 & - & $\begin{array}{l}\mathrm{SiO}_{2}-1.97 \\
\mathrm{Al}_{2} \mathrm{O}_{3}-1.10 \\
\mathrm{Cr}_{2} \mathrm{O}_{3}-0.071 \\
\mathrm{MnO}-0.25 \\
\mathrm{CaO}-0.33 \\
\mathrm{MgO}-3.38 \\
\mathrm{P}_{2} \mathrm{O}_{5}-0.05 \\
\mathrm{Na}_{2} \mathrm{O}-0.07 \\
\mathrm{~K}_{2} \mathrm{O}-<0.01\end{array}$ & [42] \\
\hline & & 36.78 & 25.85 & 29.86 & - & $\begin{array}{l}\mathrm{SiO}_{2}-4.46 \\
\mathrm{Al}_{2} \mathrm{O}_{3}-0.72 \\
\mathrm{Cr}_{2} \mathrm{O}_{3}-0.21 \\
\mathrm{MnO}-0.36 \\
\mathrm{CaO}-0.15 \\
\mathrm{MgO}-0.81 \\
\mathrm{P}_{2} \mathrm{O}_{5}-0.03 \\
\mathrm{SO}_{3}-0.21 \\
\mathrm{~V}_{2} \mathrm{O}_{5}-0.38\end{array}$ & {$[43]$} \\
\hline \multirow[t]{2}{*}{ Indonesia } & Bangka, Kalimantan & 45.35 & - & 31.48 & - & $\begin{array}{l}\mathrm{SiO}_{2}-3.29 \\
\mathrm{Al}_{2} \mathrm{O}_{3}-2.35 \\
\mathrm{Cr}_{2} \mathrm{O}_{3}-1.87 \\
\mathrm{SO}_{3}-2.24 \\
\mathrm{ZrO}_{2}-3.57 \\
\mathrm{Na}_{2} \mathrm{O}-3.86\end{array}$ & {$[44]$} \\
\hline & & 35.46 & - & 52.87 & - & $\begin{array}{l}\mathrm{SiO}_{2}-2.33 \\
\mathrm{Al}_{2} \mathrm{O}_{3}-1.61 \\
\mathrm{Cr}_{2} \mathrm{O}_{3}-0.88 \\
\mathrm{MnO}-1.07 \\
\mathrm{CaO}-0.1 \\
\mathrm{MgO}-1.81 \\
\mathrm{P}_{2} \mathrm{O}_{5}-0.17 \\
\mathrm{~K}_{2} \mathrm{O}-0.16 \\
\mathrm{SnO}_{2}-2.06\end{array}$ & {$[45]$} \\
\hline Iran & Kahnooj & 43.61 & 39.16 & 1.60 & - & $\begin{array}{l}\mathrm{SiO}_{2}-7.28 \\
\mathrm{Al}_{2} \mathrm{O}_{3}-1.94 \\
\mathrm{MnO}-1.05 \\
\mathrm{CaO}-1.90 \\
\mathrm{MgO}-2.01 \\
\mathrm{P}_{2} \mathrm{O}_{5}-0.17 \\
\mathrm{~K}_{2} \mathrm{O}-0.02 \\
\mathrm{Na}_{2} \mathrm{O}-0.23\end{array}$ & {$[46]$} \\
\hline
\end{tabular}


Table 2 (continued)

\begin{tabular}{|c|c|c|c|c|c|c|c|}
\hline Country & Region & Weight $\% \mathrm{TiO}_{2}$ & $\begin{array}{l}\text { Weight \% } \\
\text { FeO }\end{array}$ & $\begin{array}{l}\text { Weight \% } \\
\mathrm{Fe}_{2} \mathrm{O}_{3}\end{array}$ & $\begin{array}{l}\text { Weight \% } \\
\text { Total Fe }\end{array}$ & $\begin{array}{l}\text { Weight } \\
\% \\
\text { Other constituents }\end{array}$ & References \\
\hline New Zealand & Barrytown & 47.1 & 37.5 & 3.0 & - & $\begin{array}{l}\mathrm{SiO}_{2}-5.2 \\
\mathrm{Al}_{2} \mathrm{O}_{3}-2.3 \\
\mathrm{MnO}-1.7 \\
\mathrm{CaO}-1.1 \\
\mathrm{MgO}-0.2 \\
\mathrm{P}_{2} \mathrm{O}_{5}-0.2 \\
\mathrm{~K}_{2} \mathrm{O}-0.3 \\
\mathrm{~V}_{2} \mathrm{O}_{5}-0.1 \\
\mathrm{Na}_{2} \mathrm{O}-0.3\end{array}$ & [37] \\
\hline Sri Lanka & - & 53.66 & 17.48 & - & 30.04 & $\begin{array}{l}\mathrm{SiO}_{2}-1.54 \\
\mathrm{Al}_{2} \mathrm{O}_{3}-0.65 \\
\mathrm{Cr}_{2} \mathrm{O}_{3}-0.07 \\
\mathrm{P}_{2} \mathrm{O}_{5}-0.03 \\
\mathrm{~V}_{2} \mathrm{O}_{5}-0.20 \\
\mathrm{ZrO}_{2}-0.83\end{array}$ & $\begin{array}{l}{[47],} \\
{[48]}\end{array}$ \\
\hline \multirow[t]{3}{*}{ Australia } & Collie (West Australia) & 53.6 & 20.8 & 20.0 & 30.1 & $\begin{array}{l}\mathrm{SiO}_{2}-1.27 \\
\mathrm{Al}_{2} \mathrm{O}_{3}-0.58 \\
\mathrm{MnO}-1.54 \\
\mathrm{MgO}-0.25 \\
\mathrm{ZrO}_{2}-0.61 \\
\mathrm{Cr}_{2} \mathrm{O}_{3}-0.04 \\
\mathrm{Nb}_{2} \mathrm{O}_{5}-0.14 \\
\mathrm{~V}_{2} \mathrm{O}_{5}-0.11\end{array}$ & [49] \\
\hline & $\begin{array}{l}\text { Capel } \\
\text { (West Australia) }\end{array}$ & 53.6 & 20.8 & 20.0 & - & $\begin{array}{l}\mathrm{SiO}_{2} \\
\mathrm{MnO}_{2} \\
\mathrm{ZrO}_{2} \text { etc } \\
\text { All impurities-5.6 }\end{array}$ & {$[50]$} \\
\hline & Consolidated Rutile Ltd & 49.6 & 32.8 & 13.7 & 35.1 & $\begin{array}{l}\mathrm{SiO}_{2}-0.45 \\
\mathrm{Al}_{2} \mathrm{O}_{3}-0.47 \\
\mathrm{Cr}_{2} \mathrm{O}_{3}-0.25\end{array}$ & {$[51]$} \\
\hline \multirow[t]{3}{*}{ China } & Panzhihau & 47.25 & 34.21 & 5.56 & - & $\begin{array}{l}\mathrm{SiO}_{2}-2.75 \\
\mathrm{Al}_{2} \mathrm{O}_{3}-1.49 \\
\mathrm{MgO}-6.23 \\
\mathrm{MnO}_{2}-0.61\end{array}$ & {$[52]$} \\
\hline & & 45.64 & 36.45 & 6.53 & - & $\begin{array}{l}\mathrm{SiO}_{2}-3.65 \\
\mathrm{Al}_{2} \mathrm{O}_{3}-1.02 \\
\mathrm{MnO}-0.855 \\
\mathrm{MgO}-3.22 \\
\mathrm{CaO}-1.12 \\
\mathrm{~V}_{2} \mathrm{O}_{5}-<0.10\end{array}$ & {$[53]$} \\
\hline & & 47.60 & 32.81 & 7.25 & - & $\begin{array}{l}\mathrm{SiO}_{2}-3.35 \\
\mathrm{Al}_{2} \mathrm{O}_{3}-1.66 \\
\mathrm{MgO}-5.64 \\
\mathrm{MnO}_{2}-0.663 \\
\mathrm{CaO}-0.70\end{array}$ & {$[54]$} \\
\hline
\end{tabular}


Table 2 (continued)

\begin{tabular}{|c|c|c|c|c|c|c|c|}
\hline Country & Region & Weight $\% \mathrm{TiO}_{2}$ & $\begin{array}{l}\text { Weight \% } \\
\text { FeO }\end{array}$ & $\begin{array}{l}\text { Weight \% } \\
\mathrm{Fe}_{2} \mathrm{O}_{3}\end{array}$ & $\begin{array}{l}\text { Weight \% } \\
\text { Total Fe }\end{array}$ & $\begin{array}{l}\text { Weight } \\
\% \\
\text { Other constituents }\end{array}$ & References \\
\hline \multirow[t]{2}{*}{ India } & Manavalakurichi & 55.1 & 20.3 & 19.9 & - & $\begin{array}{l}\mathrm{SiO}_{2}-1.5 \\
\mathrm{Al}_{2} \mathrm{O}_{3}-0.8 \\
\mathrm{MgO}-1.0 \\
\mathrm{Cr}_{2} \mathrm{O}_{3}-0.1 \\
\mathrm{~V}_{2} \mathrm{O}_{5}-0.2 \\
\mathrm{P}_{2} \mathrm{O}_{5}-0.1 \\
\text { Rare earths- } 0.1\end{array}$ & {$[55]$} \\
\hline & Chatrapur, Orissa & 50.55 & 34.20 & 12.30 & - & $\begin{array}{l}\mathrm{SiO}_{2}-0.70 \\
\mathrm{Al}_{2} \mathrm{O}_{3}-0.45 \\
\mathrm{MnO}-0.54 \\
\mathrm{CaO}-0.05 \\
\mathrm{MgO}-0.72 \\
\mathrm{~V}_{2} \mathrm{O}_{5}-0.23 \\
\mathrm{Cr}_{2} \mathrm{O}_{3}-0.05 \\
\text { Rare earths }-0.02\end{array}$ & {$[56]$} \\
\hline
\end{tabular}

\section{Leaching methods of IImenite}

\subsection{Leaching using acids}

\subsubsection{Leaching using hydrochloric acid}

Haverkamp et al. [37] report the digestion of ilmenite found at Barrytown, Westland, New Zealand, in hydrochloric acid. The net reaction for this process is,

$$
\mathrm{FeTiO}_{3}+4 \mathrm{HCl}=\mathrm{Fe}^{2+}+\mathrm{TiO}^{2+}+4 \mathrm{Cl}^{-}+2 \mathrm{H}_{2} \mathrm{O}
$$

The temperature of digestion $\left(60^{\circ} \mathrm{C}, 80^{\circ} \mathrm{C}, 85^{\circ} \mathrm{C}\right.$ and $90^{\circ} \mathrm{C}$ ) was found to play a crucial role in the reaction of ilmenite with $10.3 \mathrm{M} \mathrm{HCl}$. Digestion increased with increasing temperature and time. However, at $90{ }^{\circ} \mathrm{C}$ digestion was reported to decrease with increasing time of digestion due to the masking of ilmenite with the precipitate of $\mathrm{TiO}(\mathrm{OH})_{2}$ formed during the reaction. Further, as the digestion reaction is exothermic it slows down the reaction at temperatures higher than the boiling point of $\mathrm{HCl}\left(84^{\circ} \mathrm{C}\right)$. It was also seen that the concentration of $\mathrm{HCl}$ decreased on increasing the temperature of digestion as the acid is consumed more readily at higher temperatures. However, at $90{ }^{\circ} \mathrm{C}$ although the concentration of $\mathrm{HCl}$ decreased, during the later stage of the digestion, the concentration of $\mathrm{HCl}$ increased through the reaction, $\mathrm{TiO}^{2+}+\mathrm{H}_{2} \mathrm{O}=\mathrm{TiO}(\mathrm{OH})_{2}+2 \mathrm{H}^{+}$[37].

A detailed study on digestion of Ilmenite from deposits in Abu Ghalaga, Egypt in $\mathrm{HCl}$ was reported by Mahmoud et al. [41]. Experiments have been carried out with and without a reducing species. Extraction of Fe was found reached a total of $29 \%$ after $5 \mathrm{~h}$ and that of Ti reached $13 \%$ after $30 \mathrm{~min}$, decreasing to $10 \%$ after $5 \mathrm{~h}$. Upon the addition of a reducing agent (iron powder, $\mathrm{Fe}^{0}$ ) to the reaction after $20 \mathrm{~min}$, the total extracted Ti reached $28 \%$ in $40-60 \mathrm{~min}$ and decreased to about $2 \%$ after 120 min, remaining unchanged with increasing time of extraction. The total extracted Fe increased after addition of Fe powder to about $45 \%$ from 40 to 60 min and then to $98 \%$ after $6 \mathrm{~h}$ clearly indicating that the total extracted $\mathrm{Ti}$ and Fe are respectively, 2 and $>2.5$ times greater when a reducing agent is used during the digestion. A significant drop in $\mathrm{HCl}$ concentration has been observed when Fe powder is used, as $\mathrm{HCl}$ reacts with $\mathrm{Fe}$ powder in addition to ilmenite. Ilmenite and hematite present in the ore react with $\mathrm{HCl}$ as follows,

$$
\begin{aligned}
& \mathrm{FeO} \cdot \mathrm{TiO}_{2}(\mathrm{~S})+4 \mathrm{HCl}(\mathrm{aq})=\mathrm{FeCl}_{2}(\mathrm{aq})+\mathrm{TiOCl}_{2}(\mathrm{aq})+2 \mathrm{H}_{2} \mathrm{O}(\mathrm{L}) \\
& \mathrm{Fe}_{2} \mathrm{O}_{3}(\mathrm{~S})+6 \mathrm{HCl}(\mathrm{aq})=\mathrm{FeCl}_{3}(\mathrm{aq})+3 \mathrm{H}_{2} \mathrm{O}(\mathrm{L})
\end{aligned}
$$


Decrease in total Ti after reaching a peak has been attributed to the hydrolysis of the dissolved Ti species.

$$
\mathrm{TiOCl}_{2}(\mathrm{aq})+\mathrm{H}_{2} \mathrm{O}(\mathrm{L})=\mathrm{TiO}_{2}(\mathrm{~S})+2 \mathrm{HCl}(\mathrm{aq})
$$

Once Fe powder is added it reacts with $\mathrm{HCl}$ to produce nascent hydrogen and ferrous chloride.

$$
\mathrm{Fe}(\mathrm{S})+2 \mathrm{HCl}(\mathrm{aq})=\mathrm{FeCl}_{2}(\mathrm{aq})+2 \mathrm{H}(\mathrm{aq})
$$

Part of the nascent hydrogen forms hydrogen gas.

$$
\mathrm{H}(\mathrm{aq})+\mathrm{H}(\mathrm{aq})=\mathrm{H}_{2}(\mathrm{~g})
$$

Nascent hydrogen and/or Fe, simultaneously reduce $\mathrm{Fe}^{3+}$ to $\mathrm{Fe}^{2+}$.

$$
\begin{gathered}
2 \mathrm{FeCl}_{3}(\mathrm{aq})+2 \mathrm{H}(\mathrm{aq})=2 \mathrm{FeCl}_{2}(\mathrm{aq})+2 \mathrm{HCl}(\mathrm{aq}) \\
2 \mathrm{FeCl}_{3}(\mathrm{aq})+\mathrm{Fe}(\mathrm{S})=3 \mathrm{FeCl}_{2}(\mathrm{aq})
\end{gathered}
$$

Further, in the presence of nascent hydrogen and $\mathrm{Fe}_{1} \mathrm{Ti}^{4+}$ in $\mathrm{TiOCl}_{2}$ is reduced to $\mathrm{Ti}^{3+}$ as indicated by the colour change from yellow-white to violet.

$$
\begin{gathered}
2 \mathrm{TiOCl}_{2}(\mathrm{aq})+2 \mathrm{HCl}(\mathrm{aq})+2 \mathrm{H}(\mathrm{aq})=2 \mathrm{TiCl}_{3}(\mathrm{aq})+2 \mathrm{H}_{2} \mathrm{O}(\mathrm{L}) \\
2 \mathrm{TiOCl}_{2}(\mathrm{aq})+\mathrm{Fe}(\mathrm{S})+4 \mathrm{HCl}(\mathrm{aq})=2 \mathrm{TiCl}_{3}(\mathrm{aq})+\mathrm{FeCl}_{2}(\mathrm{aq})+2 \mathrm{H}_{2} \mathrm{O}(\mathrm{L})
\end{gathered}
$$

Electromortive force (emf) values $2 \mathrm{H}^{+} / \mathrm{H}_{2}(0.00 \mathrm{~V}), \mathrm{Fe}^{3+} / \mathrm{Fe}^{2+}(0.77 \mathrm{~V})$ and $\mathrm{TiO}^{2+} / \mathrm{Ti}^{3+}(0.10 \mathrm{~V})$ also indicate the greater tendency for the reduction $\mathrm{Fe}^{3+}$ than $\mathrm{TiO}^{2+}$. Moreover, $\mathrm{Ti}^{3+}$ could also reduce $\mathrm{Fe}^{3+}$ as follows, when nascent hydrogen is removed from the reaction medium.

$$
\mathrm{TiCl}_{3}(\mathrm{aq})+\mathrm{FeCl}_{3}(\mathrm{aq})+\mathrm{H}_{2} \mathrm{O}(\mathrm{L})=\mathrm{TiOCl}_{2}(\mathrm{aq})+\mathrm{FeCl}_{2}(\mathrm{aq})+2 \mathrm{HCl}(\mathrm{aq})
$$

Further, the authors have optimized the parameters for the digestion as; stoichiometry of $\mathrm{HCl}-1.2$, concentration of $\mathrm{HCl}-20 \%$, temperature $-110^{\circ} \mathrm{C}$, the ratio of ilmenite to Fe powder-1.1, time that of Fe powder should be added$30 \mathrm{~min}$ from the start of the reaction and the reaction time $-5 \mathrm{~h}$ [41]. Shahien et al. [42] have also studied a chemical process whereby $\mathrm{TiO}_{2}$ was produced from ilmenite found at Abu Ghalaga, Egypt. Ilmenite has been milled in a vertical planetary ball mill to a mean particle size of $90 \mu \mathrm{m}$, mixed with carbon in a ratio of 4:1 (providing sufficient carbon for full reduction of ilmenite) and annealed at $1200^{\circ} \mathrm{C}$ in an Ar atmosphere to prevent oxidation and other undesired reactions from taking place. The resulting products of this process are $\mathrm{TiO}_{2}, \mathrm{Fe}$ and $\mathrm{CO}$.

$$
\mathrm{FeTiO}_{3}(\mathrm{~S})+\mathrm{C}(\mathrm{S})=\mathrm{TiO}_{2}(\mathrm{~S})+\mathrm{Fe}(\mathrm{S})+\mathrm{CO}(\mathrm{g})
$$

Fe has been leached from the annealed sample using $4 \mathrm{~mol} / \mathrm{L} \mathrm{HCl}$ acid at $90^{\circ} \mathrm{C}$ and the residual solid washed and calcined in air at $600^{\circ} \mathrm{C}$ to remove any carbon impurities present.

$$
\begin{gathered}
\mathrm{Fe}(\mathrm{S})+\mathrm{TiO}_{2}(\mathrm{~S})+2 \mathrm{HCl}(\mathrm{aq})=\mathrm{TiO}_{2}(\mathrm{~S})+\mathrm{FeCl}_{2}(\mathrm{aq})+\mathrm{H}_{2}(\mathrm{~g}) \\
\mathrm{FeTiO}_{3}(\mathrm{~S})+2 \mathrm{HCl}(\mathrm{aq})=\mathrm{TiO}_{2}(\mathrm{~S})+\mathrm{FeCl}_{2}(\mathrm{aq})+\mathrm{H}_{2} \mathrm{O}(\mathrm{L})
\end{gathered}
$$

However, in addition to the $\mathrm{TiO}_{2}$ (rutile), Fe-Ti Oxide phases were also present in the acid leached product. In order to remove these impurities the samples were reduced to iron metal and $\mathrm{TiO}_{2}$ by treating in $\mathrm{H}_{2}$ atmosphere under the same conditions used for the carbothermic reduction [42].

$$
\mathrm{FeTiO}_{3}(\mathrm{~S})+\mathrm{H}_{2}(\mathrm{~g})=\mathrm{Fe}(\mathrm{S})+\mathrm{TiO}_{2}(\mathrm{~S})+\mathrm{H}_{2} \mathrm{O}(\mathrm{g})
$$

Ramadan et al. [43] have studied the leaching and kinetics of Abu-Ghalaga ilmenite. The effect of $\mathrm{HCl}$ concentration on digestion of ilmenite has been studied by varying its concentration from 5 to $25 \%(5,10,15,20$ and $25 \%)$. It has been found that the leachability of iron increased linearly to $67 \%$ until the concentration of $\mathrm{HCl}$ was $20 \%$ and further increased non-linearly till the $\mathrm{HCl}$ concentration increased to $25 \%$. On the other hand, leachability of Ti increased with increasing $\mathrm{HCl}$ concentration to $20 \%$ and decreased with further increments. The effect of particle size on the dissolution of Ti and 
Fe has been studied and it was found that with decreasing particle size the leachability of both Ti and Fe increased. The optimum solid/liquid ratio was 1:6 where the maximum leachabilities of iron and titanium were $67.71 \%$ and $64.78 \%$, respectively. On increasing the ratio, a significant improvement in leachability of both titanium and iron was not observed. Another important parameter for the processing of ilmenite is the agitating speed. When the agitating speed is increased from 100 to $500 \mathrm{rpm}$ in $100 \mathrm{rpm}$ increments, the maximum percentage of titanium and iron was leached at $400 \mathrm{rpm}$ and remained the same at $500 \mathrm{rpm}$. The temperature was found to affect the dissolution of ilmenite and the leachability of both titanium and iron increased with increasing temperature up to $110^{\circ} \mathrm{C}$, and remained the same at $120^{\circ} \mathrm{C}$, the highest temperature studied. The maximum dissolution of ilmenite was obtained on agitating ilmenite with $\mathrm{HCl}$ at a speed of $400 \mathrm{rpm}$ for $300 \mathrm{~min}$ resulting in $96.37 \%$ and $92.87 \%$, leaching of iron and titanium, respectively.

The rate of dissolution could be controlled by two different mechanisms, mainly solid or product layer diffusion and chemical reaction. Kinetics of the dissolution of ilmenite in $\mathrm{HCl}$ has been studied using shrinking-core model. According to the data tabulated in Table 3 the apparent rate constant and the $R^{2}$ value of both mechanisms increased with increasing temperature. Authors conclude that the digestion of Abu-Ghalaga ilmenite has occurred via diffusion control based on the value of coefficient of determination $\left(R^{2}\right)$ (for digestion of ilmenite at $100 / 110^{\circ} \mathrm{C}, R^{2}$ value for diffusion control $=0.98$; chemical reaction $=0.86$ ). The activation energy of the process was found to be $17.603 \mathrm{~kJ} / \mathrm{mol}$ from the Arrhenius expression [43].

Researchers from Sri Lanka have studied the digestion of Sri Lankan ilmenite in acidic solutions [47, 48, 57]. Production of rutile from natural ilmenite via anion-exchange was reported to produce rutile without any traces of iron. Eluting a column containing ilmenite with $\mathrm{HCl}(20 \%)$ and passing the effluent through a second column containing IRA $410 \mathrm{Cl}$ resin indicated that $\mathrm{Fe}^{3+}$ in the effluent from the first column (containing both iron and titanium) was removed by eluting through the second column. The $\mathrm{Fe}^{3+}$ concentration of the effluent from column 1 (ilmenite only) was $380 \mathrm{ppm}$ while that from column 2 (ilmenite column followed by the ion exchange column) was $27 \mathrm{ppm}$, indicating a reduction of $93 \%$ in the iron content due to the ion exchange resin. The concentration of leached titanium was slightly lower in the effluent from column 2 than in that from column 1. The reduction in level of Ti after anion exchange was attributed to the reprecipitation of a small fraction of $\mathrm{TiOCl}_{2}$. In order to ensure the complete removal of $\mathrm{Fe}^{3+}$ from the ion exchange column, the $\mathrm{Fe}^{2+}$ in the ilmenite leachate was initially oxidized to $\mathrm{Fe}^{3+}$ by purging the ilmenite column with chlorine gas, and then converted to $\left[\mathrm{FeCl}_{4}\right]^{-}$by treatment with concentrated $\mathrm{HCl}$, allowing $\left[\mathrm{FeCl}_{4}\right]^{-}$to be retained in the anion-exchange resin. The columns were then washed with $0.6 \% \mathrm{HCl}$, the effluents were neutralized with $\mathrm{NH}_{4} \mathrm{OH}$, and the resulting precipitate was calcined at $773 \mathrm{~K}$. The resulting product was found to be $\mathrm{Fe}_{2} \mathrm{O}_{3}$. When the effluent from the anion exchange column containing $\mathrm{TiOCl}_{2}$ was neutralized with $\mathrm{NH}_{4} \mathrm{OH}$, based on the XRD pattern, the solid after calcination was found to be rutile. No traces of iron were detected by EDX analysis suggesting that the anion exchange assisted acid leaching of ilmenite is a remarkable method for the production of pure rutile [47]. The flow chart shown in Fig. 2 summarizes the main steps in synthesizing $\mathrm{TiO}_{2}$ from ilmenite via the treatment with $\mathrm{HCl}$.

\subsubsection{Leaching using sulfuric acid}

Use of sulfuric acid for the dissolution of ilmenite has been reported in the literature [58-60]. Bangka Island-Indonesia is a well-known source of ilmenite. Latifa et al. report the digestion of ilmenite by sulfuric acid where $\mathrm{TiOSO}_{4}$ is produced as the precursor material. $\mathrm{TiOSO}_{4}$ was subsequently hydrolyzed by mixing $\mathrm{H}_{2} \mathrm{O}$ and $\mathrm{TiOSO}_{4}$ in volume ratios of 3:1 and 6:1 as shown below.

Table 3 The apparent rate constant with their coefficient of determination at different temperatures. Reproduced from Ref. [43]

\begin{tabular}{lllll}
\hline Temperature $\left({ }^{\circ} \mathrm{C}\right)$ & \multicolumn{2}{l}{ Apparent rate constant $\left(\mathrm{min}^{-1}\right)$} & & \multicolumn{2}{l}{ Coefficient of determination $\left(\mathrm{R}^{2}\right)$} \\
\cline { 2 - 3 } & $\begin{array}{l}\text { Chemical control } \\
\left(\mathrm{K}_{\mathrm{c}}\right)\end{array}$ & $\begin{array}{l}\text { Diffusion control } \\
\left(\mathrm{K}_{\mathrm{d}}\right)\end{array}$ & Reaction control & Diffusion control \\
\hline 45 & 0.0011 & 0.0007 & 0.3656 & 0.6565 \\
55 & 0.0013 & 0.0009 & 0.5231 & 0.8206 \\
70 & 0.0015 & 0.0012 & 0.6738 & 0.9261 \\
85 & 0.0018 & 0.0016 & 0.7851 & 0.9643 \\
100 & 0.0021 & 0.0021 & 0.8565 & 0.9828 \\
110 & 0.0023 & 0.0023 & 0.8684 & 0.9753 \\
\hline
\end{tabular}


Fig. 2 The flow chart of synthesizing $\mathrm{TiO}_{2}$ from ilmenite treating with $\mathrm{HCl}$

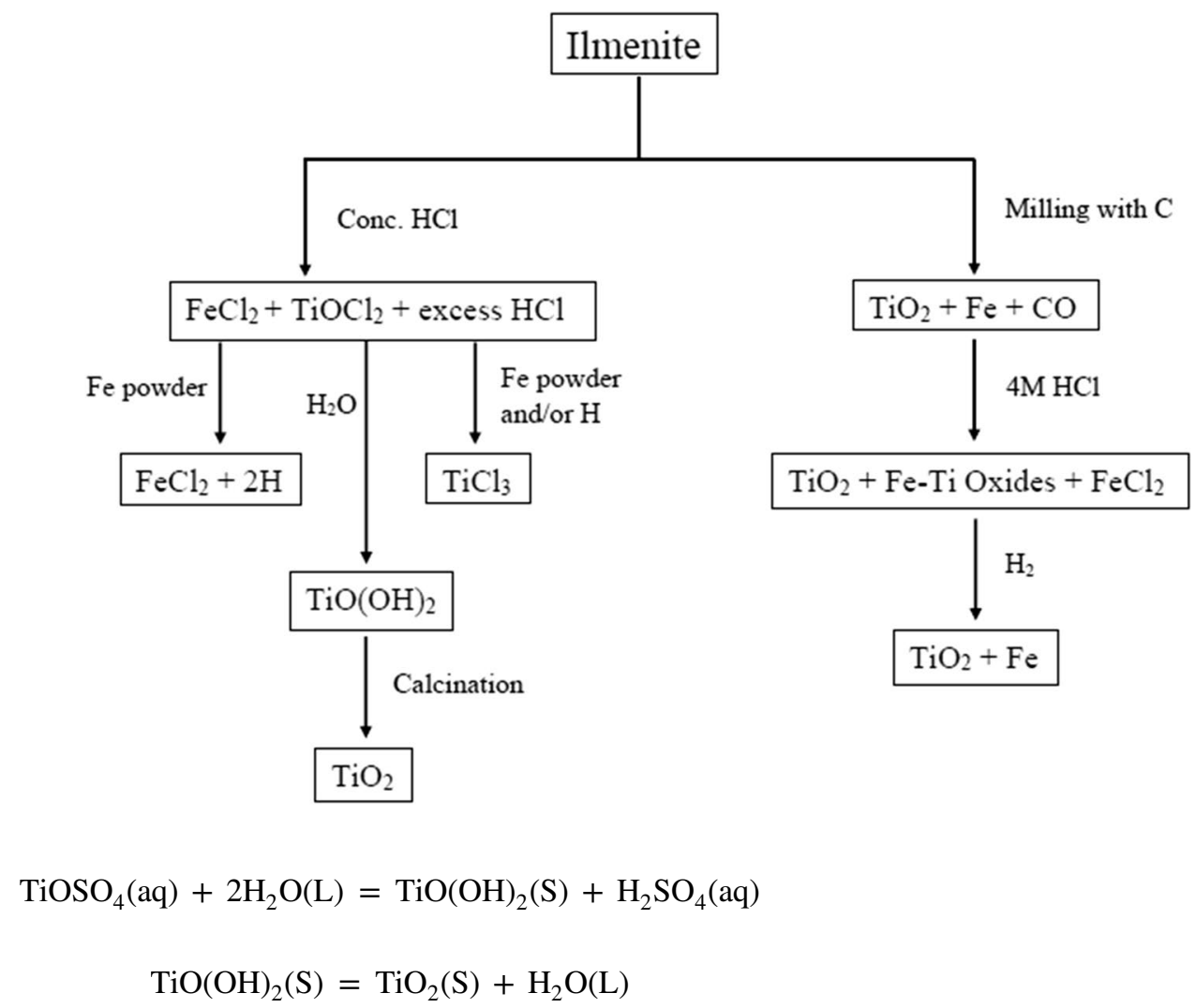

The SEM images (Fig. 3) of this study indicate that with the higher percentage of water, heavily aggregated smaller nanoparticles of about 32-40 nm resulted, and more spherical nanoparticles of 96-188 $\mathrm{nm}$ with less aggregation were formed with the lower proportion of water. However, with the addition of dextrin more spherical but larger nanoparticles resulted due to the action of dextrin as a coagulant. It neutralizes the repulsive electrical charges surrounding the $\mathrm{TiO}_{2}$ particles creating larger particles or clumps which could settle immediately and be separated. Interestingly, increasing the time of hydrolysis in the presence of dextrin, has resulted in comparatively smaller nanoparticles. Such smaller nanoparticles tend to have a lower band gap ( $3.16 \mathrm{eV}$ to $5.71 \mathrm{~nm}$ ) compared to the larger particles (3.28 eV to $9.45 \mathrm{~nm}$ ) making them more effective for photocatalytic applications. Further, during the reaction of ilmenite $\left(\mathrm{FeTiO}_{3}\right)$ with sulfuric acid, initial seeding of the mixture with Fe powder was found to increase the yield of $\mathrm{TiO}_{2}$ as it averts the
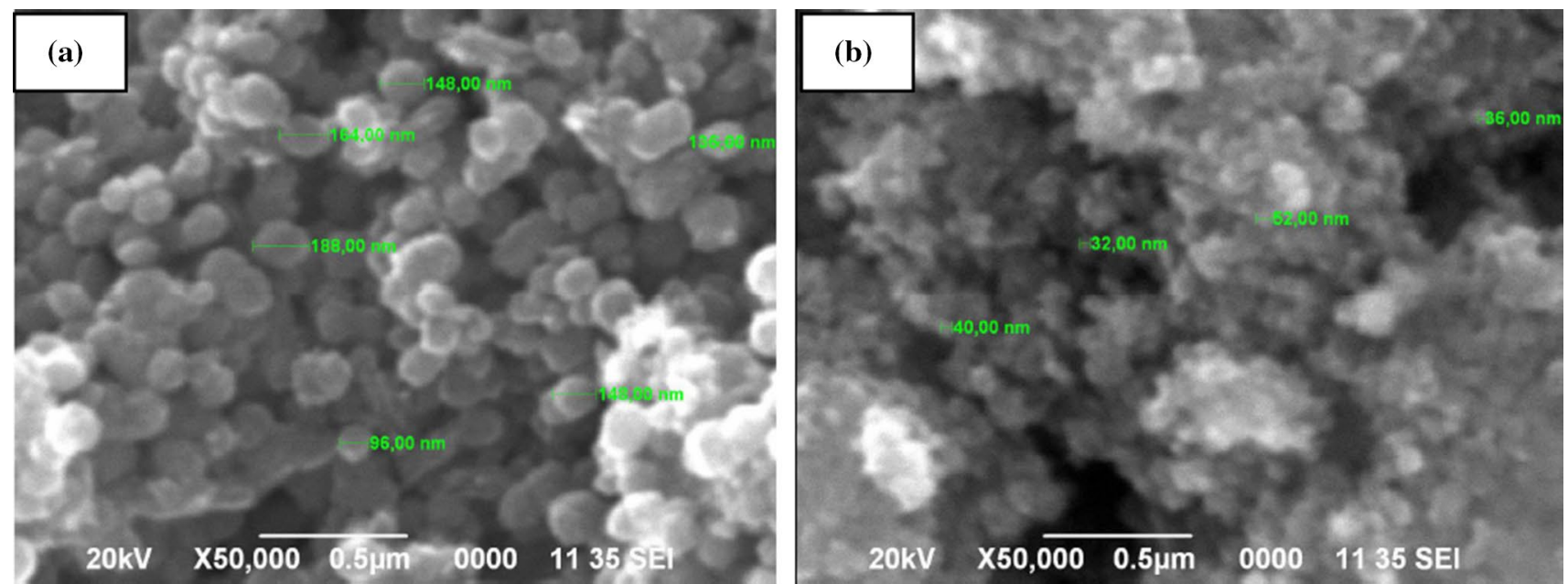

Fig. $3 \mathrm{SEM}$ images of $\mathrm{TiO}_{2}$ products at various $\mathrm{H}_{2} \mathrm{O} / \mathrm{TiOSO}_{4}$ volume ratio of $\mathbf{a}$ 3:1 and $\mathbf{b}$ 6:1. (adapted from Ref. [61]) 
Table 4 Chemical composition of Bangka ilmenite ore and the synthesized $\mathrm{TiO}_{2}$. Reproduced from Ref. [61]

\begin{tabular}{lccccccccccc}
\hline Compound & $\mathrm{TiO}_{2}$ & $\mathrm{Fe}_{2} \mathrm{O}_{3}$ & $\mathrm{SiO}_{2}$ & $\mathrm{Al}_{2} \mathrm{O}_{3}$ & $\mathrm{MnO}$ & $\mathrm{MgO}$ & $\mathrm{CaO}$ & $\mathrm{K}_{2} \mathrm{O}$ & $\mathrm{P}_{2} \mathrm{O}_{5}$ & $\mathrm{Cr}_{2} \mathrm{O}_{3}$ & $\mathrm{SnO}_{2}$ \\
\hline Ilmenite (wt\%) & 35.46 & 52.87 & 2.33 & 1.61 & 1.07 & 1.81 & 0.1 & 0.16 & 0.17 & 0.88 & 2.06 \\
$\begin{array}{l}\text { As-synthesized } \\
\mathrm{TiO}_{2} \text { powder }\end{array}$ & 92.78 & 3.19 & 2.90 & - & - & - & - & - & 0.16 & 0.02 & 0.95 \\
$\begin{array}{l}\text { without seeding } \\
\text { (wt\%) }\end{array}$ & & & & & & & & & & & \\
$\begin{array}{l}\text { As-synthesized } \\
\text { TiO } 2 \text { powder } \\
\text { with seeding } \\
\text { iron (wt\%) }\end{array}$ & 95.01 & 1.88 & 1.91 & 0.03 & - & - & - & - & 0.16 & 0.02 & 0.96 \\
\hline
\end{tabular}

Fig. 4 XRD patterns of ilmenite, the synthesized solids and the reference $\mathrm{TiO}_{2}(\bullet$ ilmenite $\checkmark$ anatase, rutile, reference $\mathrm{TiO}_{2}$ in Evonik P 25). (adapted from Ref. [63])

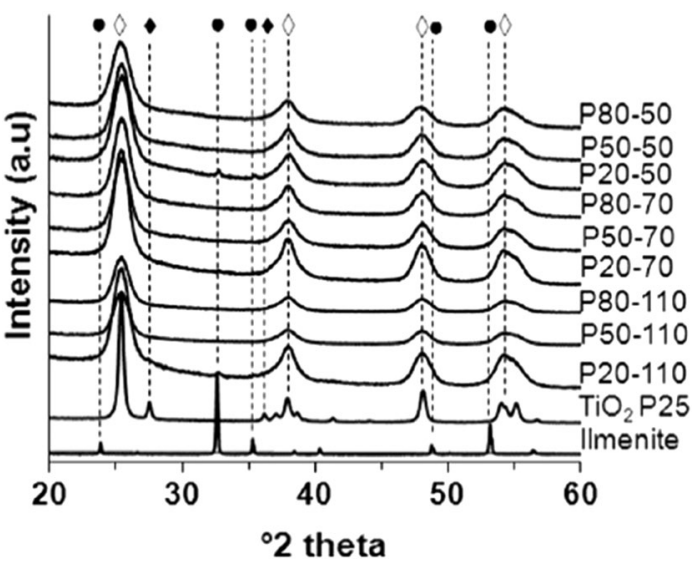

oxidation of ferrous to ferric ions, thereby preventing its co-precipitation with the product $\left(\mathrm{TiO}_{2}\right)$ deteriorating its quality. Table 4 summarizes the chemical composition of Bangka ilmenite and the $\mathrm{TiO}_{2}$ obtained with and without seeding iron powder. The anatase phase was identified as the crystal state of all $\mathrm{TiO}_{2}$ nanoparticles synthesized. However, their crystallinity was poor as they were only dried at $110^{\circ} \mathrm{C}$ for $3 \mathrm{~h}$. As expected; the crystallinity could be improved by drying for $24 \mathrm{~h}$ or by calcining at $400{ }^{\circ} \mathrm{C}$ [61].

Jia et al. [62] reported the pressure leaching of Panzhihua ilmenite by sulfuric acid. The effect of temperature on titanium and iron leaching has been studied in the range of $110-150^{\circ} \mathrm{C}$. Leaching of iron was found to increase with increasing temperature up to $140^{\circ} \mathrm{C}$ and levelled off thereafter. A maximum Fe extraction of $76 \%$ was achieved. However, for titanium the percentage extracted decreased with increasing temperature, with less than $1 \%$ at $150^{\circ} \mathrm{C}$. This is attributed to the hydrolysis of titanium during leaching. The effect of sulfuric acid concentration on leaching of ilmenite has been studied in the range of $10-50 \mathrm{wt} \%$. Percentage Fe extraction was found to increase with increasing acid concentration to $40 \mathrm{wt} \%$ (94\% extraction) and decrease with further with increase. Optimal acid/ore ratio for ilmenite leaching was determined to be 2:1 (w/w) at an optimal reaction time of $3 \mathrm{~h}$. Generation of a large amount of sulfuric acid waste is a drawback of the sulfuric acid process. In order to reduce the sulfuric acid waste $\mathrm{Fe}^{2+}$ was added to the reaction mixture in varying concentration. However, Fe extraction from ilmenite gradually decreased with increasing concentration of externally added $\mathrm{Fe}^{2+}$. This was attributed to the decrease in free water and thus increasing the effective sulfuric acid concentration. Further, loss of titanium increased with increasing $\mathrm{Fe}^{2+}$ concentration as hydrolysis of titanium is inhibited by high concentrations of sulfuric acid [62].

$\mathrm{Fe}$ doped $\mathrm{TiO}_{2}$ materials have been synthesized from natural ilmenite found in Columbia. Briefly, ilmenite was digested in sulfuric acid of varying concentration $(20 \%, 50 \%$, and $80 \%)$ at three temperatures $\left(50,70\right.$ and $\left.110^{\circ} \mathrm{C}\right)$ for 90 min. $\mathrm{Fe}^{3+}$ ions were partially reduced to $\mathrm{Fe}^{2+}$ by adding iron powder and the resulting solution was cooled to $10^{\circ} \mathrm{C}$ to remove the iron(II) sulfate heptahydrate crystals. $\mathrm{pH}$ of the remaining solution containing iron(III) ions and titanium polyhydroxycationic species was adjusted to 12 by adding $\mathrm{NaOH}$, and the resulting precipitate was calcined at $400^{\circ} \mathrm{C}$. In general, high quantities of titanium could be extracted when high concentrations of sulfuric acid were used at higher temperatures. The amount of iron extracted at 50 and $70^{\circ} \mathrm{C}$ decreased when the concentration of sulfuric acid was decreased. At sulfuric acid concentrations of 50 and $80 \%$, the extracted content of iron increased when the temperature was decreased. X-ray diffraction patterns (Fig. 4) clearly showed the presence of the anatase phase of $\mathrm{TiO}_{2}$ but no crystalline peaks relevant to iron were present indicating 
the isomorphic substitution of $\mathrm{Fe}^{3+}$ ions. The presence of iron was confirmed by $\mathrm{X}$-ray fluorescence. Brunauer-Emmett-Teller surface area analysis of all the synthesized samples were found be higher than that of $\mathrm{P} 25 \mathrm{TiO}_{2}$. Further, the resulting band gap measured by UV-Visible diffuse reflectance spectroscopy showed lower values for the synthesized materials than for $\mathrm{P} 25 \mathrm{TiO}_{2}$, suggesting that the synthesized $\mathrm{Fe}$ doped $\mathrm{TiO}_{2}$ materials from natural ilmenite are better visible light active photocatalysts [63]. The synthesis of $\mathrm{TiO}_{2}$ from ilmenite via digestion in $\mathrm{H}_{2} \mathrm{SO}_{4}$ is shown in Fig. 5 .

\subsubsection{Leaching using hydrochloric acid and sulfuric acid}

IImenite obtained from Bangka, Indonesia was subjected to a more elaborate digestion procedure by Refs. [44, 64-66]. IImenite was preoxidized in open air for $6 \mathrm{~h}$ at temperatures ranging from 400 to $1100^{\circ} \mathrm{C}$. It has been observed that the preoxidation process improves the formation of pseudobrookite as an intermediate product in the formation $\mathrm{TiO}_{2}$. The product of oxidation contained ilmenite, hematite and rutile in the temperature range of $400-800^{\circ} \mathrm{C}$ and at higher temperatures $(900,1000$ and $1100^{\circ} \mathrm{C}$ ) pesudobrookite was formed in addition to hematite and rutile. Dissolution of non preoxidized ilmenite in $\mathrm{HCl}$ was studied by varying the concentration and it was evident that both ferrous and titanium dissolved increasingly with increasing concentration of $\mathrm{HCl}$, with ferrous dissolving more than titanium. Addition of $\mathrm{Fe}^{0}$ in a ratio of ilmenite to $\mathrm{Fe}, 2: 1$ to the digestion process has shown increased dissolution of the pesuodobrookite phase and a gain in anatase, rutile and hematite. However, the formation of pesudobrookite was found to be less prominent when $\mathrm{Na}_{2} \mathrm{~S}$ was added to ilmenite at the preoxidation process thus facilitating dissolution. When ilmenite is roasted at $800^{\circ} \mathrm{C}$ it produces $\mathrm{TiO}_{2}$ and $\mathrm{Fe}_{2} \mathrm{O}_{3}$ as shown below.

$$
2 \mathrm{FeOTiO}_{2}(\mathrm{~S})+1 / 2 \mathrm{O}_{2}(\mathrm{~g})=\mathrm{Fe}_{2} \mathrm{O}_{3}(\mathrm{~S})+2 \mathrm{TiO}_{2}(\mathrm{~S})
$$

When $\mathrm{Na}_{2} \mathrm{~S}$ is added to ilmenite before roasting,

$$
\begin{aligned}
& 4 \mathrm{FeTiO}_{3}(\mathrm{~S})+2 \mathrm{TiO}_{2}(\mathrm{~S})+2 \mathrm{Fe}_{2} \mathrm{O}_{3}(\mathrm{~S})+6 \mathrm{Na}_{2} \mathrm{~S}(\mathrm{~S})+7 \mathrm{O}_{2}(\mathrm{~g})=\mathrm{Na}_{4} \mathrm{Ti}_{5} \mathrm{O}_{12}(\mathrm{~S}) \\
& \quad+5 \mathrm{NaFeO}_{2}(\mathrm{~S})+\mathrm{NaFeS}_{2}(\mathrm{~S})+\mathrm{Na}_{2} \mathrm{SO}_{4}(\mathrm{aq})+\mathrm{TiO}_{2}(\mathrm{~S})+\mathrm{Fe}_{2} \mathrm{O}_{3}(\mathrm{~S})+3 \mathrm{SO}_{3(\mathrm{~g})}
\end{aligned}
$$

Upon treatment with $\mathrm{H}_{2} \mathrm{SO}_{4}(3,3.5,4.5,6$ and $9 \mathrm{M})$ the following reactions may occur and it was found that the ilmenite was more soluble in $6 \mathrm{M} \mathrm{H}_{2} \mathrm{SO}_{4}$.

$$
\begin{aligned}
& \mathrm{FeTiO}_{3}(\mathrm{~S})+2 \mathrm{H}_{2} \mathrm{SO}_{4}(\mathrm{aq})=\mathrm{FeSO}_{4}(\mathrm{aq})+\mathrm{TiOSO}_{4}(\mathrm{aq})+2 \mathrm{H}_{2} \mathrm{O}(\mathrm{L}) \\
& \mathrm{TiO}_{2}(\mathrm{~S})+\mathrm{Fe}_{2} \mathrm{O}_{3}(\mathrm{~S})+4 \mathrm{H}_{2} \mathrm{SO}_{4}(\mathrm{aq})=\mathrm{TiOSO}_{4}(\mathrm{aq})+\mathrm{Fe}_{2}\left(\mathrm{SO}_{4}\right)_{3}(\mathrm{aq})+3 \mathrm{H}_{2} \mathrm{O}(\mathrm{L}) \\
& \mathrm{NaFeO}_{2}(\mathrm{~S})+\mathrm{NaFeS}_{2}(\mathrm{~S})+4 \mathrm{H}_{2} \mathrm{SO}_{4}(\mathrm{aq})=\mathrm{Na}_{2} \mathrm{SO}_{4}(\mathrm{aq})+\mathrm{Fe}_{2}\left(\mathrm{SO}_{4}\right)_{3}(\mathrm{aq})+2 \mathrm{H} \mathrm{O}(\mathrm{L})+2 \mathrm{H}_{2} \mathrm{~S}(\mathrm{aq}) \\
& \mathrm{Na}_{4} \mathrm{Ti}_{5} \mathrm{O}_{12}(\mathrm{~S})+7 \mathrm{H}_{2} \mathrm{SO}_{4}(\mathrm{aq})=5 \mathrm{TiOSO}_{4}(\mathrm{aq})+2 \mathrm{Na}_{2} \mathrm{SO}_{4}(\mathrm{aq})+7 \mathrm{H}_{2} \mathrm{O}(\mathrm{L})
\end{aligned}
$$

Fig. 5 The flow chart of synthesizing $\mathrm{TiO}_{2}$ from ilmenite via digestion in $\mathrm{H}_{2} \mathrm{SO}_{4}$

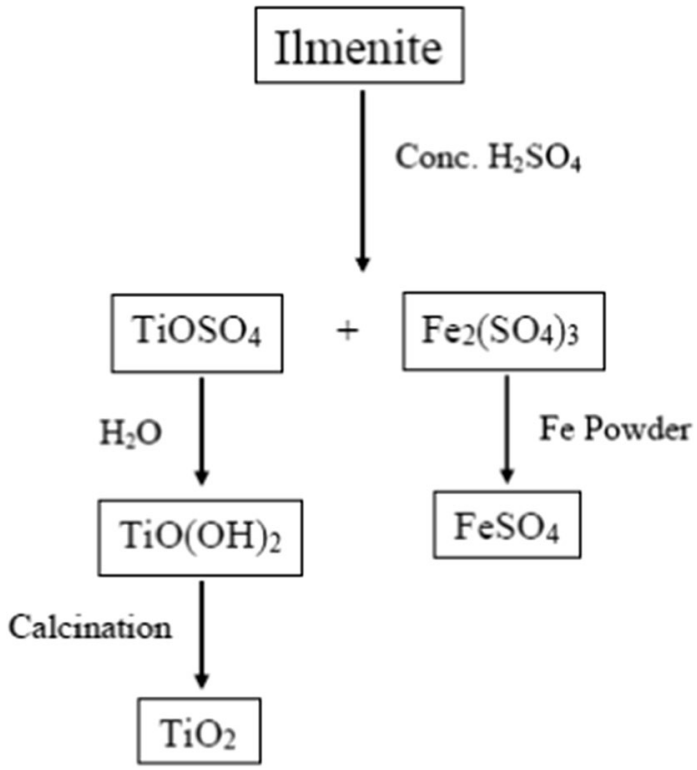


$\mathrm{Fe}^{2+}$ and $\mathrm{Fe}^{3+}$ ions are complexed with $\mathrm{KSCN}$ to prevent the contamination of the intermediate $\mathrm{TiO}(\mathrm{OH})_{2}$ formed during the hydrolysis-condensation process of titanyl sulfate to produce $\mathrm{TiO}_{2}$ as the final product $[44,64-66]$,

$$
\begin{aligned}
& \mathrm{TiOSO}_{4}(\mathrm{aq})+2 \mathrm{H}_{2} \mathrm{O}(\mathrm{L})=\mathrm{TiO}(\mathrm{OH})_{2}(\mathrm{~S})+\mathrm{H}_{2} \mathrm{SO}_{4}(\mathrm{aq}) \\
& \mathrm{TiO}(\mathrm{OH})_{2}(\mathrm{~S})=\mathrm{TiO}_{2}(\mathrm{~S})+\mathrm{H}_{2} \mathrm{O}(\mathrm{L})
\end{aligned}
$$

Arachchi et al. [48] report the digestion of ilmenite roasted with $\mathrm{ZnO}$ or $\mathrm{ZnS}$, in $\mathrm{HCl}_{\text {or }} \mathrm{H}_{2} \mathrm{SO}_{4}$. Briefly, ilmenite was finely ground with $\mathrm{ZnO}$ or $\mathrm{ZnS}$ roasted at $900^{\circ} \mathrm{C}$ for $4 \mathrm{~h}$ and the roasted product was digested in $5 \mathrm{M} \mathrm{HCl}$ at $30^{\circ} \mathrm{C}$ and $6 \mathrm{M} \mathrm{HCl}$ at $110^{\circ} \mathrm{C}$. Ilmenite decomposes to pseudobrookite and rutile above $800^{\circ} \mathrm{C}[67,68]$. Ilmenite was also roasted with $\mathrm{ZnO} /$ $\mathrm{ZnS}$, in Ti to $\mathrm{Zn}$ molar ratio of 1:2. The main products were $\mathrm{Zn}_{2} \mathrm{TiO}_{4}$ and $\mathrm{Fe}_{3} \mathrm{O}_{4}$ as given below.

$$
\begin{aligned}
& 6 \mathrm{FeTiO}_{3}(\mathrm{~S})+12 \mathrm{ZnO}(\mathrm{S})+\mathrm{O}_{2}(\mathrm{~g})=6 \mathrm{Zn}_{2} \mathrm{TiO}_{4}(\mathrm{~S})+2 \mathrm{Fe}_{3} \mathrm{O}_{4}(\mathrm{~S}) \\
& 6 \mathrm{FeTiO}_{3}(\mathrm{~S})+12 \mathrm{ZnS}(\mathrm{S})+19 \mathrm{O}_{2}(\mathrm{~g})=6 \mathrm{Zn}_{2} \mathrm{TiO}_{4}(\mathrm{~S})+2 \mathrm{Fe}_{3} \mathrm{O}_{4}(\mathrm{~S})+12 \mathrm{SO}_{2}(\mathrm{~S})
\end{aligned}
$$

On treatment of normal ilmenite, roasted ilmenite, roasted ilmenite with $\mathrm{ZnO}$ or $\mathrm{ZnS}$, with $\mathrm{HCl}$ or $\mathrm{H}_{2} \mathrm{SO}_{4}, \mathrm{TiOCl}_{2}$ and $\mathrm{TiOSO}_{4}$ were the titanium based products while $\mathrm{FeCl}_{2}, \mathrm{FeCl}_{3}$ and $\mathrm{FeSO}_{4}$ were produced as iron based compounds with some $\mathrm{ZnCl}_{2}$ and $\mathrm{ZnSO}_{4}$.

$$
\begin{aligned}
& \mathrm{FeTiO}_{3}(\mathrm{~S})+4 \mathrm{HCl}(\mathrm{aq})=\mathrm{TiOCl}_{2}(\mathrm{aq})+\mathrm{FeCl}_{2}(\mathrm{aq})+\mathrm{H}_{2} \mathrm{O}(\mathrm{L}) \\
& \mathrm{FeTiO}_{3}(\mathrm{~S})+2 \mathrm{H}_{2} \mathrm{SO}_{4}(\mathrm{aq})=\mathrm{TiOSO}_{4}(\mathrm{aq})+\mathrm{FeSO}_{4}(\mathrm{aq})+2 \mathrm{H}_{2} \mathrm{O}(\mathrm{L}) \\
& \mathrm{Zn}_{2} \mathrm{TiO}_{4}(\mathrm{~S})+6 \mathrm{HCl}(\mathrm{aq})=\mathrm{ZnCl}_{2}(\mathrm{aq})+\mathrm{TiOCl}_{2}(\mathrm{aq})+3 \mathrm{H}_{2} \mathrm{O}(\mathrm{L}) \\
& \mathrm{Fe}_{3} \mathrm{O}_{4}(\mathrm{~S})+8 \mathrm{HCl}(\mathrm{aq})=2 \mathrm{FeCl}_{3}(\mathrm{aq})+\mathrm{FeCl}_{2}(\mathrm{aq})+4 \mathrm{H}_{2} \mathrm{O}(\mathrm{L}) \\
& \mathrm{ZnO}(\mathrm{S})+2 \mathrm{HCl}(\mathrm{aq})=\mathrm{ZnCl}_{2}(\mathrm{aq})+\mathrm{H}_{2} \mathrm{O}(\mathrm{L}) \\
& \mathrm{Zn}_{2} \mathrm{TiO}_{4}(\mathrm{aq})+3 \mathrm{H}_{2} \mathrm{SO}_{4}(\mathrm{aq})=2 \mathrm{ZnSO}_{4}(\mathrm{aq})+\mathrm{TiOSO}_{4}(\mathrm{aq})+3 \mathrm{H}_{2} \mathrm{O}(\mathrm{L}) \\
& \mathrm{Fe}_{3} \mathrm{O}_{4}(\mathrm{~S})+4 \mathrm{H}_{2} \mathrm{SO}_{4}(\mathrm{aq})=\mathrm{Fe}_{2}\left(\mathrm{SO}_{4}\right)_{3}(\mathrm{aq})+\mathrm{FeSO}_{4}(\mathrm{aq})+4 \mathrm{H}_{2} \mathrm{O}(\mathrm{L}) \\
& \mathrm{ZnO}(\mathrm{S})+\mathrm{H}_{2} \mathrm{SO}_{4}(\mathrm{aq})=\mathrm{ZnSO}_{4}(\mathrm{aq})+\mathrm{H}_{2} \mathrm{O}(\mathrm{L})
\end{aligned}
$$

Roasted ilmenite showed the lowest dissolution rates in both $\mathrm{HCl}$ and $\mathrm{H}_{2} \mathrm{SO}_{4}$ while normal ilmenite showed slightly higher dissolution in both acids. Leaching kinetics in $\mathrm{H}_{2} \mathrm{SO}_{4}$ are greater than in $\mathrm{HCl}$ for all the samples as shown in Fig. 6, due to the higher strength of the acid used and high temperature at which the digestion was performed. Results clearly indicated that the $\mathrm{ZnS}$ and $\mathrm{ZnO}$ roasted ilmenite samples exhibit higher dissolution rates in both acids for iron (Fig. 6 (i) and (ii), respectively for $\mathrm{HCl}$ and $\mathrm{H}_{2} \mathrm{SO}_{4}$ ) and titanium (Fig. 6 (iii) and (iv), respectively for $\mathrm{HCl}$ and $\mathrm{H}_{2} \mathrm{SO}_{4}$ ). Zinc could be regenerated from the final solution $[69,70]$ and interestingly zinc sulfide minerals such as Sphalerite [71] could be used in the process described here specially in industry. The separation process described could be used to produce $\mathrm{TiO}_{2}$ and $\mathrm{ZnO}$ simultaneously. The $\mathrm{SO}_{2}$ that is produced during roasting of ilmenite with $\mathrm{ZnS}$, could be used in the manufacturing process of sulfuric acid [48]. This group further reports that iron leaching from ilmenite in $\mathrm{HCl}$ was greatly enhanced when exposed to UV light due to the photoinduced degradation of the titanium oxy polymers formed and non-deposition of $\mathrm{Ti}(\mathrm{IV})$ polymeric species in pores of ilmenite. The enhanced dissolution has taken place at high temperature and high concentration of $\mathrm{HCl}$ and interestingly, when air was purged during $\mathrm{UV}$ exposure, dissolution was further enhanced due to the formation of oxidizing radical species such as $\mathrm{OH}$ and $\mathrm{HO}_{2}$, confirmed by the enhanced dissolution observed with the addition of $\mathrm{H}_{2} \mathrm{O}_{2}$ to the ilmenite $\mathrm{HCl}$ medium [57]. Figure 7 shows the main steps involve in weak acid digestion of ilmenite and subsequent production of $\mathrm{TiO}_{2}$.

\subsubsection{Leaching using weak acids}

Palliyaguru et al. [72] report the synthesis of titanium phosphate from ilmenite for cosmetic applications. Specifically, ilmenite sand was treated with $85 \%$ phosphoric acid for $5 \mathrm{~h}$ at $150^{\circ} \mathrm{C}$ and the mixture was allowed to cool and settle, with unreacted ilmenite settling at the bottom and less dense $\mathrm{Ti}\left(\mathrm{HPO}_{4}\right)_{2} \cdot \mathrm{H}_{2} \mathrm{O}$ settling on top of it showing two clearly distinct solid layers. Ti( $\left(\mathrm{HPO}_{4}\right)_{2} \cdot \mathrm{H}_{2} \mathrm{O}$ was separated from unreacted ilmenite, and dried followed by calcination at $900{ }^{\circ} \mathrm{C}$ for $4 \mathrm{~h}$. After calcination water molecules of $\mathrm{Ti}\left(\mathrm{HPO}_{4}\right)_{2} \cdot \mathrm{H}_{2} \mathrm{O}$ were removed to produce $\mathrm{TiP}_{2} \mathrm{O}_{7}$ which is a white in coloured compound. The XRD pattern of both compounds show no peaks relevant to any iron species. However, EDX spectra show the presence trace amounts of iron. Less iron remained on treatment of ilmenite with phosphoric acid due to the formation 

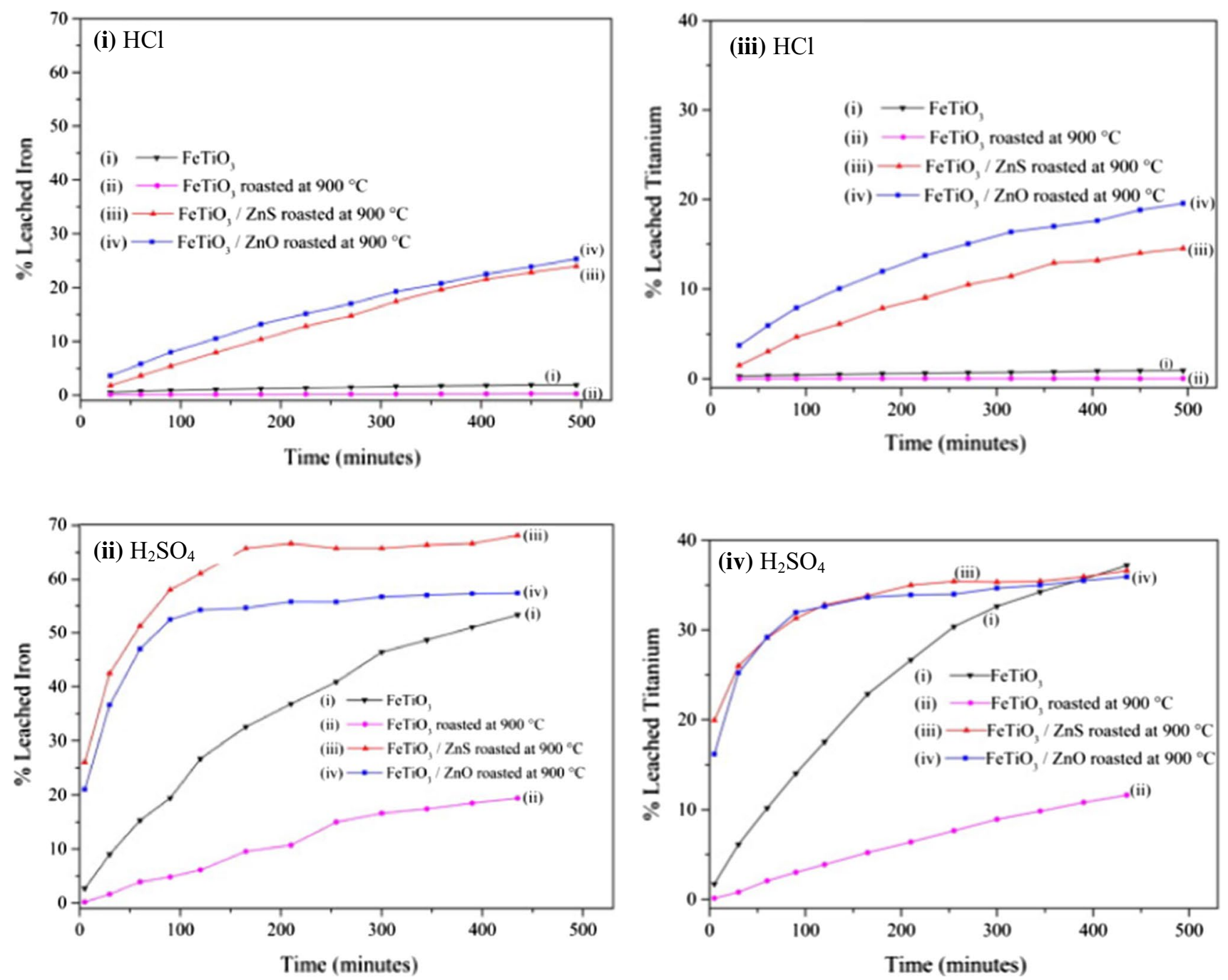

Fig. 6 Total leached of iron (i) and (ii) and titanium (iii) and (iv) in $5 \mathrm{M} \mathrm{HCl}$ at $30^{\circ} \mathrm{C}$ and in $6 \mathrm{M} \mathrm{H}_{2} \mathrm{SO}_{4}$ at $110{ }^{\circ} \mathrm{C}$, respectively. (adapted from Ref. [48])

of multiligand complexes such as $\mathrm{Fe}\left(\mathrm{H}_{2} \mathrm{PO}_{4}\right)^{2+}, \mathrm{FeH}_{5}\left(\mathrm{PO}_{4}\right)_{2}{ }^{2+}$ and $\mathrm{FeH}_{7}\left(\mathrm{PO}_{4}\right)^{3+}$, which are highly soluble. Pigments used in cosmetics are required to possess low photoactivity in order to minimize sebum breakdown on the skin [73]. Photoactivity of the synthesized $\mathrm{Ti}\left(\mathrm{HPO}_{4}\right)_{2} \cdot \mathrm{H}_{2} \mathrm{O}$ and $\mathrm{TiP}_{2} \mathrm{O}_{7}$ have been tested along with pigment grade $-\mathrm{TiO}_{2}$ and $\mathrm{P} 25-\mathrm{TiO}_{2}$ on photoreduction of 2,2-diphenyl-1-picrylhydrazyl radical (DPPH) under UV irradiation. It has been found that synthesized $\mathrm{Ti}\left(\mathrm{HPO}_{4}\right)_{2} \cdot \mathrm{H}_{2} \mathrm{O}$ and $\mathrm{TiP}_{2} \mathrm{O}_{7}$ are more photoinactive than pigment grade- $\mathrm{TiO}_{2}$ and $\mathrm{P}_{2} 5-\mathrm{TiO}_{2}$. Water retention (WR) ability is another important parameter in cosmetic products. WR capacity of the above mentioned four compounds were tested in the presence of urea as urea is commonly used as an additive to maintain the moisture level and smoothness of the on the skin [74]. WR capacity of $\mathrm{TiP}_{2} \mathrm{O}_{7}(30 \%$ after $7 \mathrm{~h})$ was found to be higher than that of $\mathrm{Ti}\left(\mathrm{HPO}_{4}\right)_{2} \cdot \mathrm{H}_{2} \mathrm{O}$ and control $\mathrm{TiO}_{2}$ samples. Hence, synthesized white colour $\mathrm{TiP}_{2} \mathrm{O}_{7}$ is a better candidate for the preparation of cosmetics than commercially available $\mathrm{TiO}_{2}$ [72]. In a similar study Palliyaguru et al. have synthesized $\mathrm{TiO}_{2}$ in anatase and rutile polymorphs. The difference in the synthetic procedure is that, after obtaining $\mathrm{Ti}\left(\mathrm{HPO}_{4}\right)_{2} \cdot \mathrm{H}_{2} \mathrm{O}$, it is reacted with $25 \% \mathrm{NH}_{3}$ followed by calcination at various temperatures $\left(500,700,800\right.$ and $\left.900{ }^{\circ} \mathrm{C}\right)$. Sample calcined at $500^{\circ} \mathrm{C}$ showed the presence of only anatase phase, while at 700 and $800^{\circ} \mathrm{C}$ both anatase and rutile phases were present. Rutile was the only phase identified in the sample calcined at $900^{\circ} \mathrm{C}$. Rate of photodegradation of Rhodamine $\mathrm{B}$ by the synthesized anatase $\mathrm{TiO}_{2}$ under UV irradiation $\left(25.4 \times 10^{-3} \mathrm{~min}^{-1}\right)$ is much higher than with synthesized rutile, $1.24 \times 10^{-3} \mathrm{~min}^{-1}$ and commercially available anatase and rutile $\mathrm{TiO}_{2}[75]$.

Jonglertjunya et al. [76] report the dissolution of titanium and iron by weak acids including citric acid and oxalic acid. It has been found that 35\% $\mathrm{Ti}$ and $9 \%$ iron have been leached when ilmenite was treated with $1 \mathrm{M}$ citric acid for $5 \mathrm{~h}$ at 
Fig. 7 The flow chart of synthesizing $\mathrm{TiO}_{2}$ from ilmenite via digestion in $\mathrm{HCl}$ and $\mathrm{H}_{2} \mathrm{SO}_{4}$

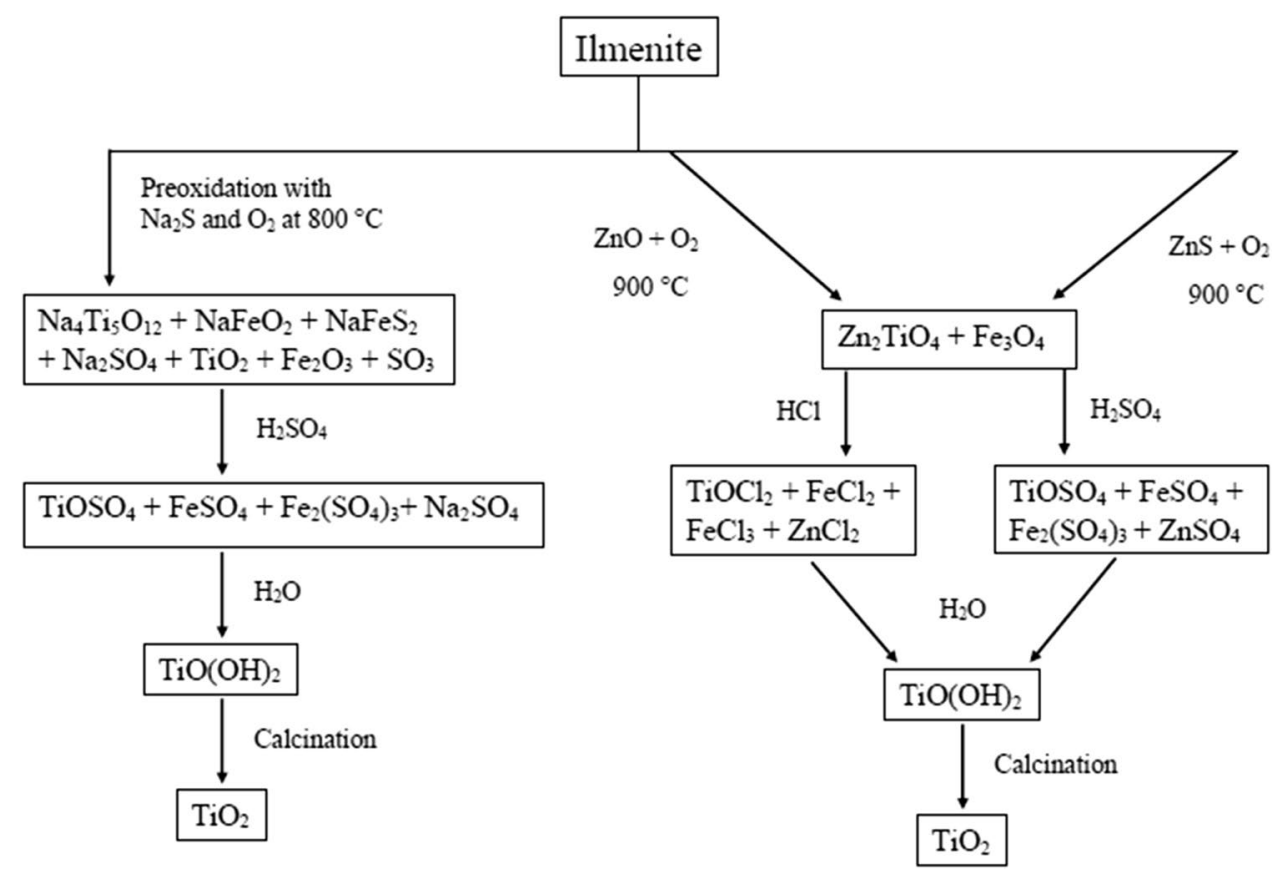

$90^{\circ} \mathrm{C}$. Further, though the titanium dissolution increased with increased time of dissolution, dissolution of iron was constant after reaching the maximum. For example, dissolution of Ti was $39 \%$ after exposure to the acid for $5 \mathrm{~h}$ and upon exposure to acid for $20 \mathrm{~h}, 63 \% \mathrm{Ti}$ was leached. However, after a $6 \mathrm{~h}$ of reaction time $10 \%$ iron was found to dissolve and the percentage did not increase even after $10 \mathrm{~h}$. The leachability of both $\mathrm{Ti}$ and iron by citric acid were lower than by a strong acid of high concentration (8 M sulfuric acid). However, a higher Ti to iron dissolution ratio was obtained with a low concentration of weak acid (1 M citric acid). Low iron dissolution was attributed to the precipitation of iron occurred in $1 \mathrm{M}$ citric acid solution at high temperature. Dissolution of Ti and iron in citric acid could be presented as follows [76],

$$
\begin{aligned}
& \mathrm{C}_{6} \mathrm{H}_{8} \mathrm{O}_{7}+\mathrm{H}_{2} \mathrm{O}=\mathrm{H}_{3} \mathrm{O}^{+}+\mathrm{C}_{6} \mathrm{H}_{7} \mathrm{O}_{7}^{-} \\
& \mathrm{FeTiO}_{3}+4 \mathrm{H}_{3} \mathrm{O}^{+}=\mathrm{TiO}^{2+}+\mathrm{Fe}^{2+}+6 \mathrm{H}_{2} \mathrm{O}
\end{aligned}
$$

Nayl et al. [77] report the dissolution of $\mathrm{Ti}$ and $\mathrm{Fe}$ in $\mathrm{KOH}$ treated ilmenite in $80 \%$ oxalic acid. The authors find that the dissolution of $\mathrm{Ti}(93 \%)$ had not change after $3 \mathrm{~h}$ while that of $\mathrm{Fe}(73 \%)$ had increased slightly. Maximum dissolution of titanium and iron resulted with $80 \%$ oxalic acid in the range of acid concentration studied (20-80\%). Effect of temperature on dissolution of ilmenite in oxalic acid was studied in the range of $20-200^{\circ} \mathrm{C}$. Percentage of Ti extracted was found to decrease at temperatures higher than $150^{\circ} \mathrm{C}$ due to the hydrolysis of titanium while recovery of iron increased with increasing temperature [77]. Figure 8 indicates the synthesis of $\mathrm{TiO}_{2}$ and titanium related products by ilmenite via digestion in weak acids.

\subsection{Leaching using alkaline solutions}

Digestion of ilmenite in acid medium has several disadvantages such as high energy consumption and corrosion of the reactors due to the use of high temperatures and acid concentrations. To mitigate such drawbacks dissolution of ilmenite has been investigated under alkaline conditions. Liu et al. [78] report the decomposition of ilmenite in concentrated $\mathrm{KOH}$ solution. The reaction of ilmenite with $\mathrm{KOH}$ produces potassium titanate $\left(\mathrm{K}_{4} \mathrm{Ti}_{3} \mathrm{O}_{8}\right)$ as indicated follows,

$$
3 \mathrm{FeTiO}_{3}+4 \mathrm{KOH}=\mathrm{K}_{4} \mathrm{Ti}_{3} \mathrm{O}_{8}+3 \mathrm{FeO}+2 \mathrm{H}_{2} \mathrm{O}
$$

It has been found that extraction of titanium increases with increasing stirring speed only up to $100 \mathrm{~min}^{-1}$ and remain constant thereafter in the tested range of 500 to $1200 \mathrm{~min}^{-1}$. High extraction of Ti resulted with smaller particle size of ilmenite with particles in the range of 58-75 $\mu \mathrm{m}$ showing the maximum extraction in the range of particle size studied (58-75 to $160-180 \mu \mathrm{m})$. Maximum titanium extraction resulted with alkali $(84 \mathrm{wt} . \% \mathrm{KOH})$ to ilmenite ratio of 7:1, and at $260^{\circ} \mathrm{C}$ [78]. In another study Liu et al. [79] report the removal of $\mathrm{Al}, \mathrm{Si}, \mathrm{Ca}$ and Fe from ilmenite to produce more pure $\mathrm{TiO}_{2}$. 
Fig. 8 The synthesis of $\mathrm{TiO}_{2}$ and titanium related products by ilmenite via digestion in weak acids

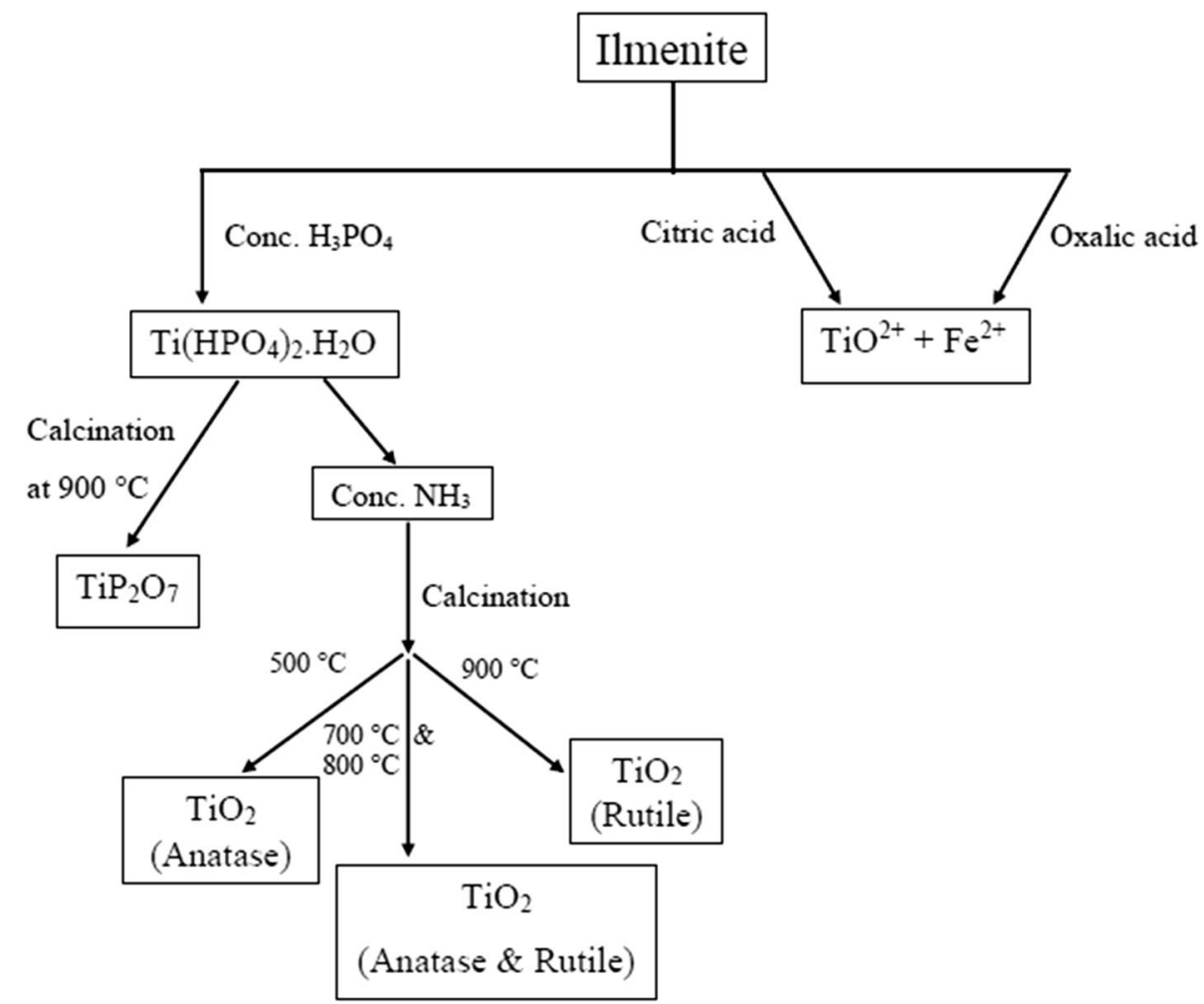

Interestingly, production of $90 \%$ pure $\mathrm{TiO}_{2}$ from Iranian ilmenite is reported [80]. Briefly, ilmenite has been mixed with $\mathrm{KOH}$ pellets and of $\mathrm{DI}$ water and heated in a reactor at $220^{\circ} \mathrm{C}$ for $3 \mathrm{~h}$. The powder obtained after the drying process has been treated with $9 \mathrm{M} \mathrm{HCl}$ and Na-EDTA at $80^{\circ} \mathrm{C}$. Na-EDTA was added as the chelating agent to separate iron impurity from the leachate. Then $25 \% \mathrm{NH}_{3}$ was added drop wise to the leachate and the obtained product was dried followed by calcination at $500{ }^{\circ} \mathrm{C}$. The synthesized $\mathrm{TiO}_{2}$ nanoparticles were almost pure, but some impurities have also been detected. $\mathrm{Na}_{2} \mathrm{O}$ was present due to the use of Na-EDTA. Overall, Ti recovery was about $70 \%$ because of loss due to chelation. The solution obtained after adding Na-EDTA consists of Fe(III)-EDTA complex, potassium, ammonium, sodium and chloride ions which are found to be required for plant growth [81] suggesting that it has some economic value [80]. Table 5 provides the details of ilmenite leaching with different reagents. The main steps involved in the synthesis of $\mathrm{TiO}_{2}$ from ilmenite via treating in alkaline solutions is given in Fig. 9.

\subsection{Leaching using ammonium chloride solution}

$\mathrm{TiO}_{2}$ is known to use as a white pigment. The presence of iron even in minor quantities make it undesirable to use as a pigment and hence a technique to prepare synthetic rutile from ilmenite was investigated where synthetic rutile would be subsequently used as the raw material in the chloride route to produce $\mathrm{TiO}_{2}$ pigment. Therefore, to upgrade the $\mathrm{TiO}_{2}$ content produced from ilmenite sand, $\mathrm{Fe}^{2+}$ and $\mathrm{Fe}^{3+}$ are reduced to metallic iron treating with carbon in which carbon acts as the reducing agent and the fuel for the kiln [82].

$$
\text { Ilmenite }+\mathrm{C}=\mathrm{Fe}+\mathrm{TiO}_{2}
$$

Subsequently, metallic iron is removed from the reduced ilmenite by treating it with oxygen dissolved ammonium chloride. A high $\mathrm{pH}$ value would be generated at the surface during the reduction of dissolved oxygen as follows,

$$
\mathrm{O}_{2}(\mathrm{aq})+2 \mathrm{H}_{2} \mathrm{O}+4 \mathrm{e}=4 \mathrm{OH}^{-}(\mathrm{aq})
$$

Ammonium ions prevent the production of high $\mathrm{pH}$ values by buffering the $\mathrm{OH}^{-}$ions and thus prevent the formation of iron (II) hydroxide which would limit the diffusion of $\mathrm{Fe}^{2+}$ from the rutile matrix.

Further, ammonia is produced due to the buffering action of ammonium ions as follows, 


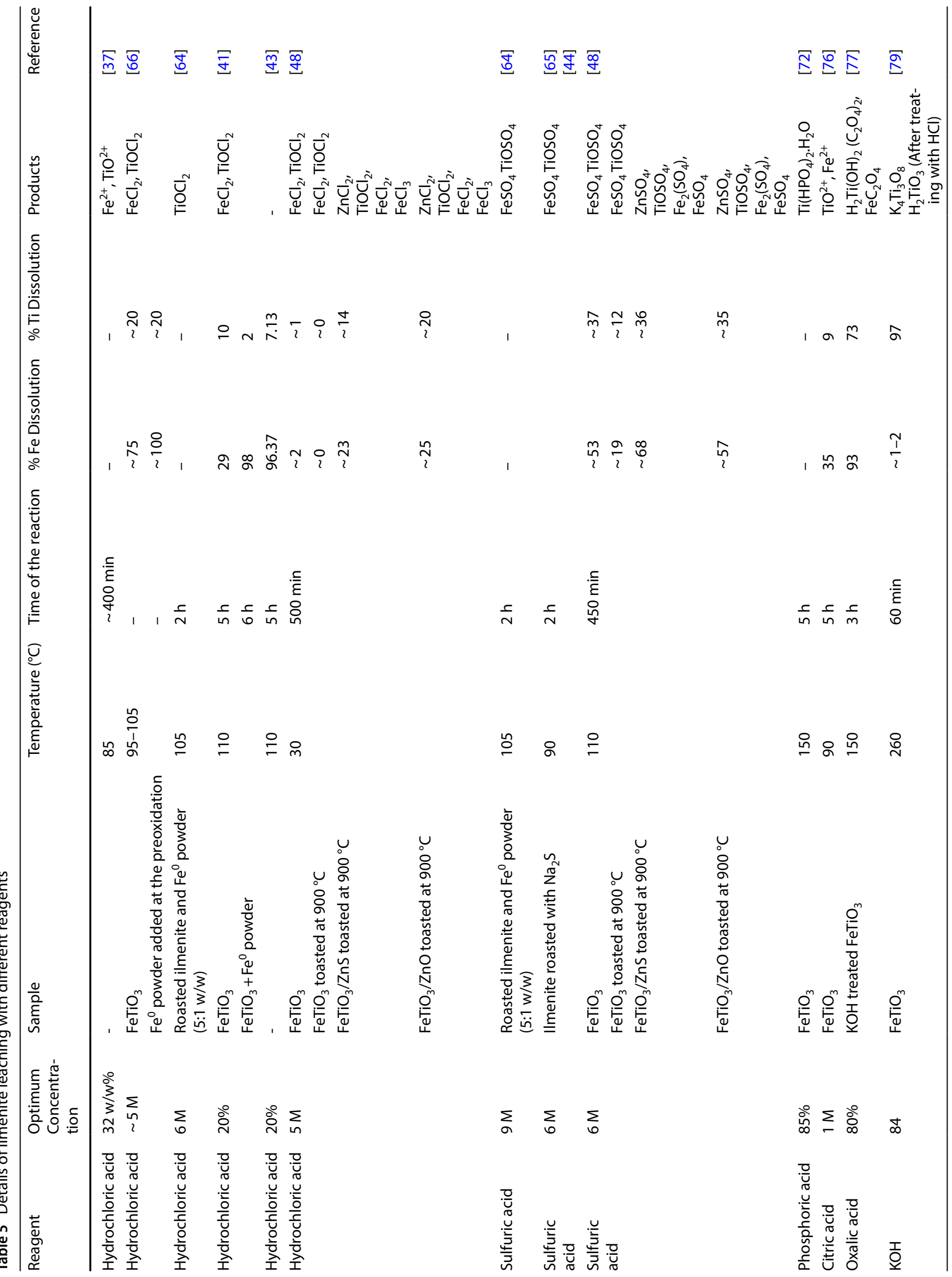




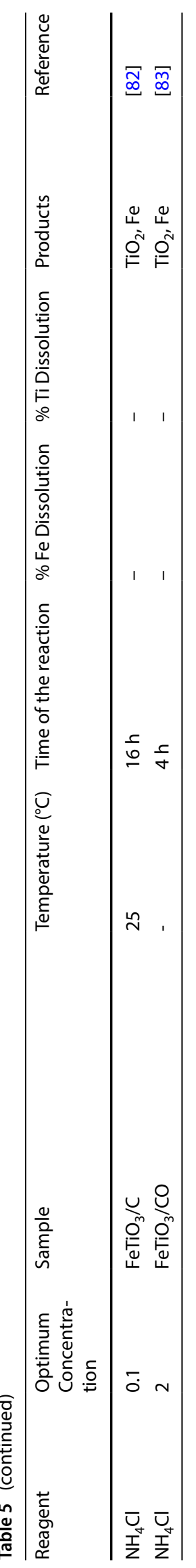


Fig. 9 A flow chart representing the main steps in producing $\mathrm{TiO}_{2}$ from ilmenite via alkaline treatment

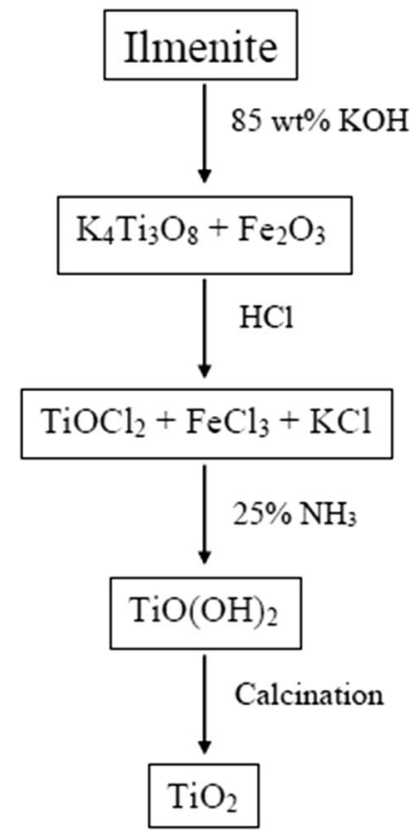

$$
\mathrm{NH}_{4}^{+}(\mathrm{aq})+\mathrm{OH}^{-}(\mathrm{aq})=\mathrm{NH}_{3}(\mathrm{aq})+\mathrm{H}_{2} \mathrm{O}
$$

Such produced $\mathrm{NH}_{3}$ complexes with $\mathrm{Fe}^{2+}$ (as shown below) until they also move away from the high $\mathrm{pH}$ values and hence prevent the production of iron (II) hydroxide in the pores of rutile.

$$
\left[\mathrm{Fe}\left(\mathrm{H}_{2} \mathrm{O}\right)_{6}\right]^{2+}+\mathrm{x} \mathrm{NH}_{3}=\left[\mathrm{Fe}\left(\mathrm{NH}_{3}\right)_{\mathrm{x}}\left(\mathrm{H}_{2} \mathrm{O}\right)_{6-\mathrm{x}}\right]^{2+}+\mathrm{xH}_{2} \mathrm{O}
$$

Moreover, $\mathrm{Cl}^{-}$ions would help to breakdown any passive oxide which may produce during aeration [82].

Farrow et al. [82] further studied the relationship between the rate of reaction and the stirring speed. They found that the rate of reaction increased with the increasing stirring speed at the low-speed range and reached a maximum. The rate remains constant when the stirring speed is further increased. Further, they studied the effect of temperature on the rate of reaction. The most important criterion is the effect of temperature on the flux of molecular oxygen to the surface of reduced ilmenite. It has been found that the rate of reaction increased up to $70^{\circ} \mathrm{C}$ and decreased when the temperature is increased further. Zhao et al. [83] report a comparative study of the content of the $\mathrm{TiO}_{2}$ and iron produced using ammonium chloride and $\mathrm{HCl}$ as the solvents. It has been found that when the ammonium chloride concentration is increased from 2 to $8 \%$, the metallic iron content in the synthetic rutile increased from $1.85 \%$ to $6.75 \%$, the total iron content decreased from $19.63 \%$ to $16 \%$ and the $\mathrm{TiO}_{2}$ content increased from $64.97 \%$ to $70 \%$ because though the concentration of ammonium chloride is increased it is not conductive to the aeration leaching process. Then the effect of using a mixture of solvents, hydrochloric acid and ammonium chloride has been studied where the $\mathrm{NH}_{4} \mathrm{Cl}$ concentration was maintained at $2 \%$ while the concentration of $\mathrm{HCl}$ was varied from 0 to $3 \%$. The total ion content and the metallic iron content decreased with the increasing concentration of $\mathrm{HCl}$, while the $\mathrm{TiO}_{2}$ content increased. Further, synthetic rutile could be upgraded to $90 \%$ by using only $\mathrm{HCl}$ because the aeration is better in $\mathrm{HCl}$ compared to ammonium chloride [83]. Ward et al. [84] studied the effectivity of diammonium chloride as the aeration catalyst and the results were compared with that of ammonium chloride. It has been found that the optimum concentration of ethylenediammonium chloride required is $0.0698 \mathrm{M}$ which is $75 \%$ of the optimum concentration of ammonium chloride $(0.093 \mathrm{M})$. The reason for the requirement of a low concentration of ethylenediammonium chloride to leach reduced ilmenite is the presence of two ammonium groups that could complex with iron. However, the required concentration is not half of the optimum concentration of ammonium chloride because of the steric hindrance of ethylenediammonium chloride complexing with iron is limited. Further, it has been found that the aeration completes in $6.0 \mathrm{~h}$ with ethylenediammonium chloride while $7.0 \mathrm{~h}$ were required with ammonium chloride suggesting that there are some advantages of using 
Fig. 10 Stepwise production of $\mathrm{TiO}_{2}$ from ilmenite via the treatment in ammonium chloride

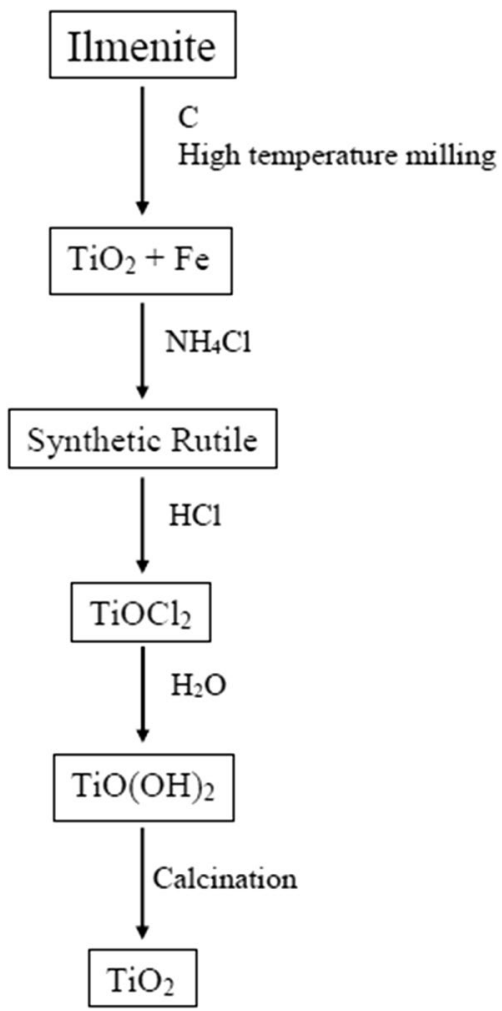

ethylenediammonium chloride than ammonium chloride [84]. The flow chart shown in Fig. 10 indicates the main steps in synthesizing $\mathrm{TiO}_{2}$ from ilmenite via the treatment involving ammonium chloride.

\subsection{Information from characterization techniques}

This review highlights the various treatment methods use to facilitate the dissolution of ilmenite producing mainly $\mathrm{Ti}^{4+}$ and $\mathrm{Fe}^{3+}$. Further, production of $\mathrm{TiO}_{2}$ from ilmenite is also discussed.

Table 6 summarizes the nature of the synthesized $\mathrm{TiO}_{2}$ including mineralogy, shape, size (either particle or crystallite), surface area, porosity and band gap characterized by various techniques; x-ray diffractometry, scanning electron microscopy, transmission electron microscopy, dynamic light scattering, Brunauer-Emmett-Teller analysis, diffuse reflectance UV-Visible spectroscopy. Reported data indicate that highly pure $\mathrm{TiO}_{2}$ where $\mathrm{Fe}_{2} \mathrm{O}_{3}$ is present as the main impurity in some cases but in low concentrations is produced by almost all the treatment methods. Presence of impurities such as $\mathrm{Fe}_{2} \mathrm{O}_{3}$ have altered the theoretical band gap values [75]. Produced Titania contains either anatase or rutile polymorphs or both anatase and rutile. In some cases different crystal structures such as $\mathrm{TiP}_{2} \mathrm{O}_{7}\left[{ }^{72}\right]$ and $\mathrm{FeTiO}_{3}$ [85] have been formed. Different shapes including spheres, rods, fibers, tubes have been produced with dimensions mostly in the nanoscale. According to the data on surface area analysis, $\mathrm{TiO}_{2}$ have high surface area due to the presence of mesopores. Reported treatment methods are promising for the synthesis $\mathrm{TiO}_{2}$ by using naturally available ilmenite as the raw material.

\subsection{Advantages and disadvantages of the treatment methods}

Production of titanium based different structural compounds from ilmenite by number methods has been discussed in this review. However, each method possesses its own advantages and disadvantages. Leaching of ilmenite in $\mathrm{HCl}$ is known to remove many impurities from ilmenite producing less contaminated $\mathrm{TiO}_{2}$ while high acid concentrations are found to corrode the reactors used for the digestion. Sulfuric acid causes less corrosion and can extract titanium from low grade titanium sources, although it generates a high amount of solid and acid waste. Leaching in weak acids like citric acid requires low acid concentration. This process extracts more titanium than iron but consumes more energy. 


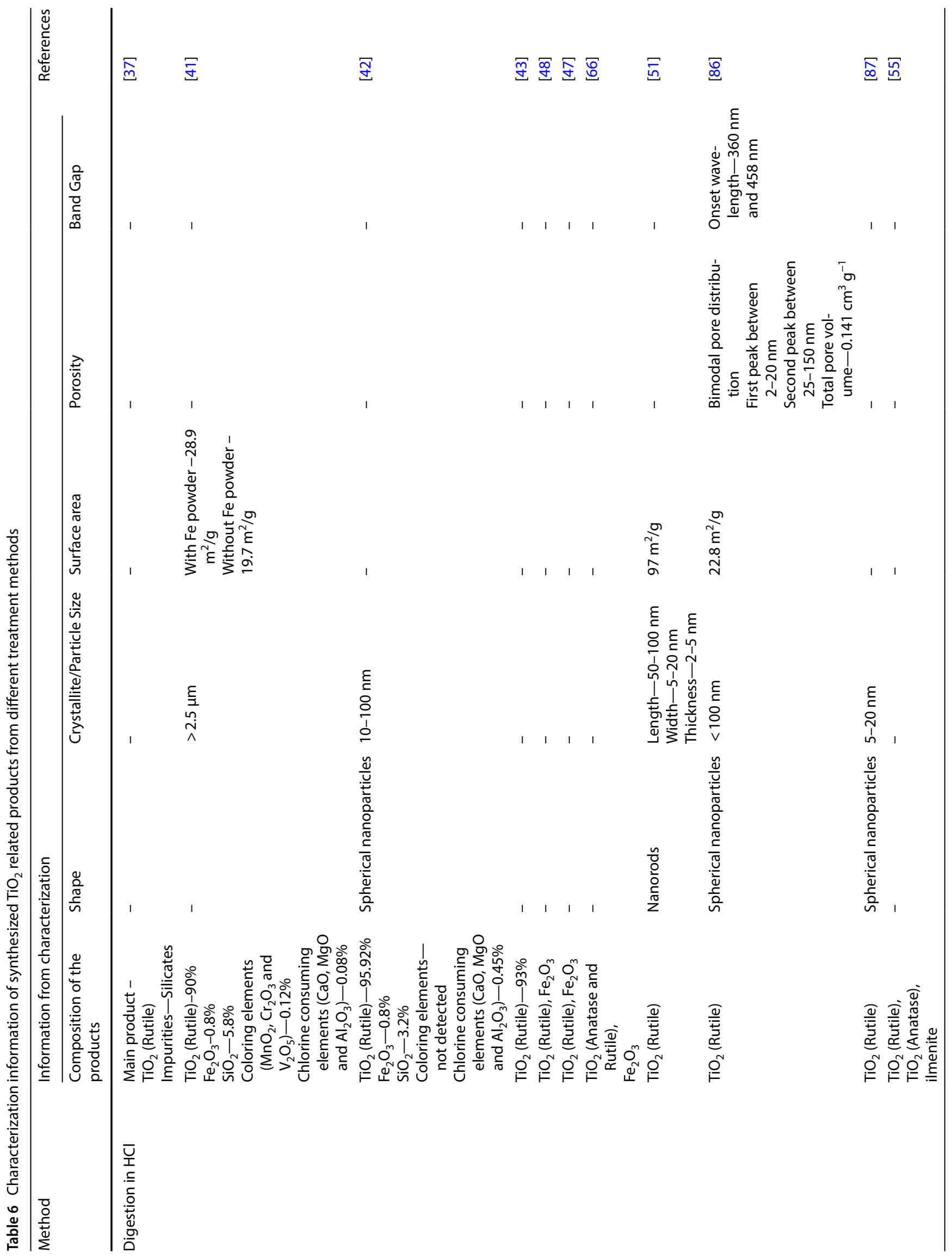




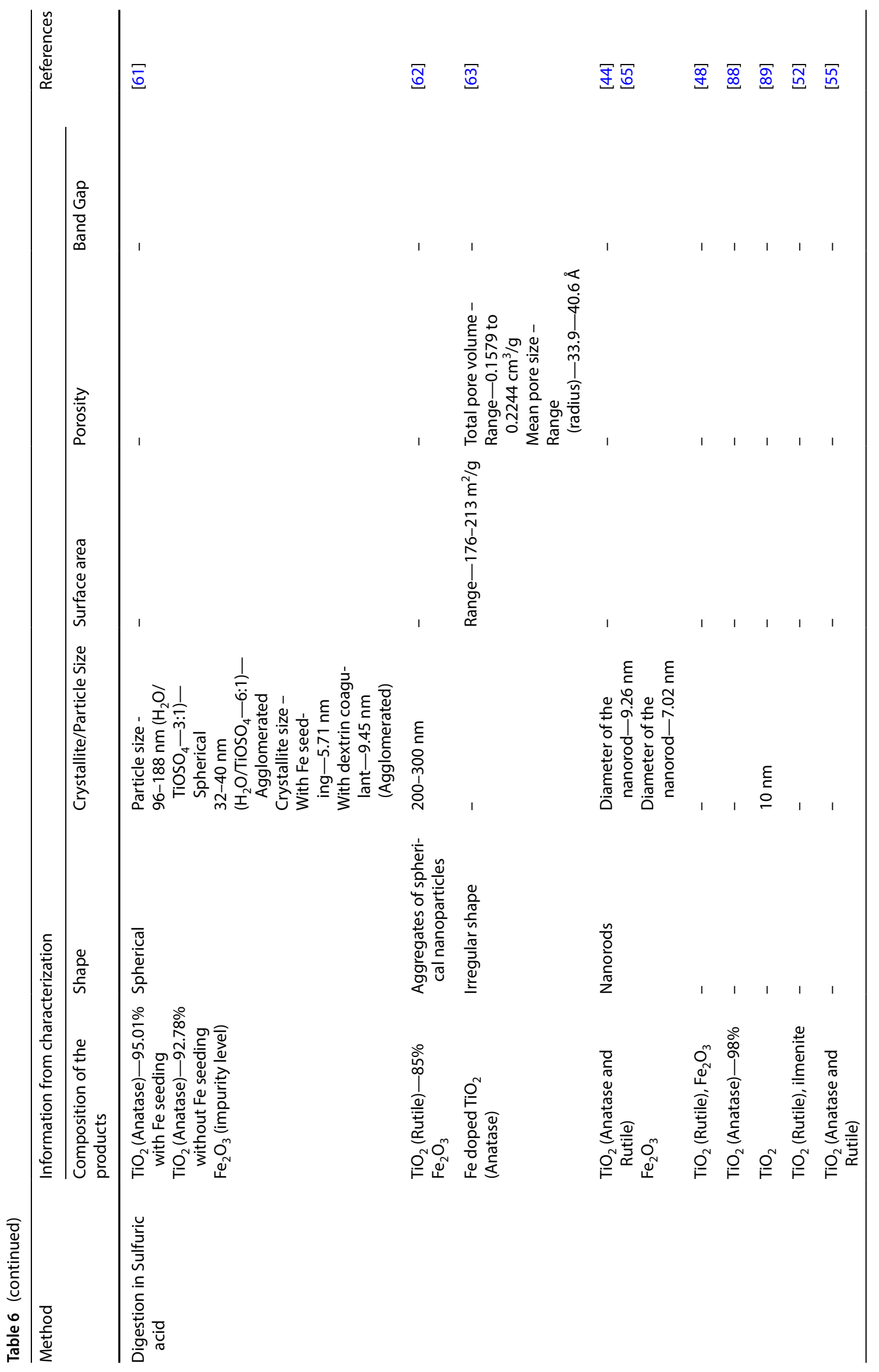




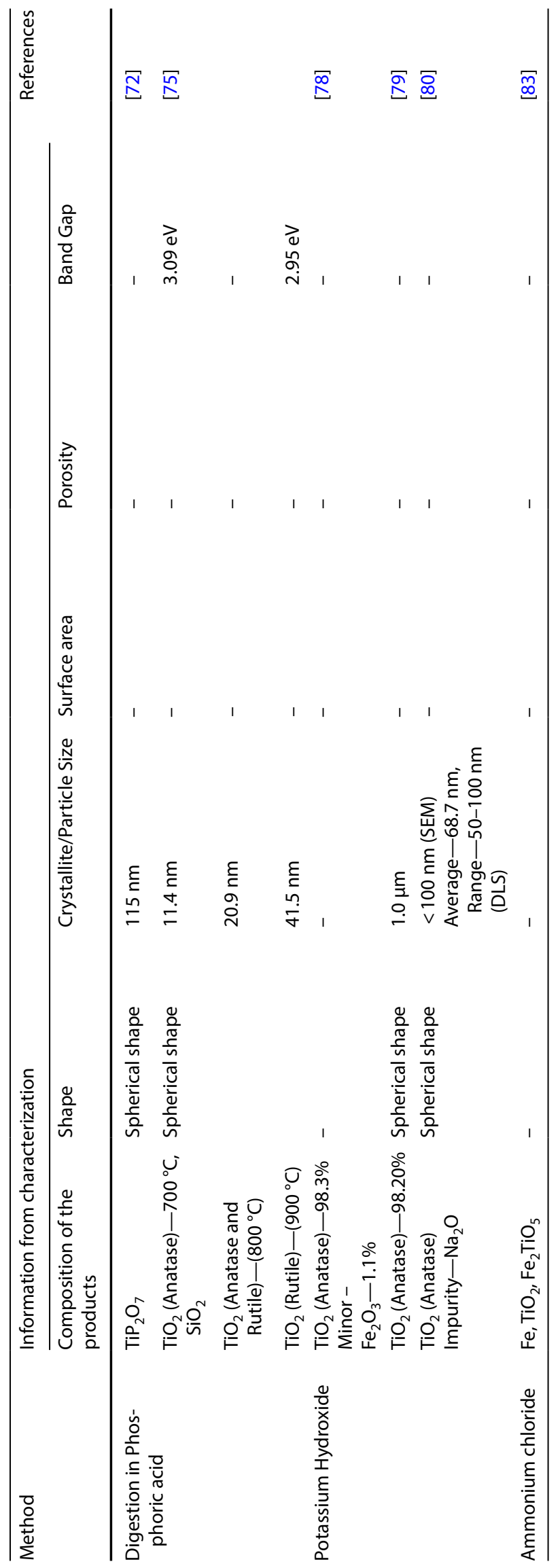


As with weak acids, leaching in alkaline medium also extracts comparatively more titanium than iron, but requires an additional acid treatment step to obtain the final products. Particle size of ilmenite can be readily reduced via ball milling causing an enhanced dissolution in acidic medium, but energy consumption is high in mechanical activation. Compounds that are produced by hydrothermal treatment are homogeneous in composition, size, and shape. However, the process requires specific equipment. The advantages and disadvantages of each method are tabulated in Table 7. It is evident that all the reported methods have disadvantages. Hence, it is wise to use a combination of methods to produce different titanium based nanostructures from natural ilmenite.

\section{Research Gaps and Future Perspectives}

A study on selective isolation of highly pure $\mathrm{TiO}_{2}$ from ilmenite would be beneficial in the industry view of point as pure $\mathrm{TiO}_{2}$ is used as a white pigment worldwide [20]. $\mathrm{TiO}_{2}$ doped with transition metals like Fe [97], $\mathrm{Cu}$ [98], $\mathrm{Cr}$ [99], $\mathrm{Mn}$ [100], non-metals such as N [101], C [102], S [103] and co-doped with metal and non-metal including N-Fe-Cu [104], N-Cu [105] have been applied to various applications including $\mathrm{H}_{2}$ production, photodegradation, antimicrobial activity etc. [34]. These nanomaterials have been synthesized by different titanium precursors such as Titanium isopropoxide [30], titanium butoxide[31], titanium oxyacetylacetonate [32], titanium tetrachloride [33]. As revealed above $\mathrm{TiO}_{2}$ produced by several techniques contain small amounts of iron. If the iron concentration can be maintained at desired small values compared to the concentration of titanium, iron doped $\mathrm{TiO}_{2}$ could be easily synthesized. Doping can be further elaborated to other metals such as $\mathrm{Cu}, \mathrm{Ag}$, Au etc. as well as non-metals like N, C, and S by adding proper precursors externally [34]. This would much broaden the scope and the applicability of using ilmenite as the raw material to prepare the titanium precursors. According to our knowledge, such synthesis methods have not been reported to compare their efficiency with the doped materials synthesized by existing chemical precursors. We believe that a simple co-precipitation method could be used to synthesize doped $\mathrm{TiO}_{2}$ from natural ilmenite. For example, a solution containing iron added to $\mathrm{TiOCl}_{2}$ can be easily precipitated by using ammonia. $\mathrm{N}$ doped $\mathrm{TiO}_{2}$ may be easily synthesized by using urea where it will act as the $\mathrm{N}$ source and the base to precipitate [104]. Moreover, doping can be done right after obtaining $\mathrm{TiO}_{2}$ as it has not been crystallized yet. In such instances, desired metal salts such as $\mathrm{FeCl}_{3}, \mathrm{CuCl}_{2}, \mathrm{AgNO}_{3}$ dissolved in deionized water could be added to $\mathrm{TiO}_{2}$ before heating and calcination. Overnight stirring followed by heating and calcination would result in doped $\mathrm{TiO}_{2}$. This method could be implemented in synthesizing non-metal doped $\mathrm{TiO}_{2}$ as well. For example, urea could be added at a proper concentration to just produced $\mathrm{TiO}_{2}$ to synthesize $\mathrm{N}$ doped $\mathrm{TiO}_{2}$. Such research projects have not

Table 7 Advantages and disadvantages of treatment methods

\begin{tabular}{|c|c|c|c|}
\hline Method & Advantages & Disadvantages & References \\
\hline \multicolumn{4}{|l|}{ Strong acid digestion } \\
\hline Hydrochloric acid & $\begin{array}{l}\text { High efficiency of Ti extraction } \\
\text { High impurity removal capability } \\
\text { Easy regeneration of } \mathrm{HCl} \\
\text { Recyclability of } \mathrm{HCl}\end{array}$ & $\begin{array}{l}\text { Required titanium high grade ilmenite } \\
\text { Require high acid concentration } \\
\text { Corrodes the reactors/consumables } \\
\text { High energy consumption } \\
\text { High cost } \\
\text { Problems in solid-liquid separation } \\
\text { Production of high } \mathrm{CO}_{2} \text { especially in large scale production }\end{array}$ & {$[62,90-93]$} \\
\hline Sulfuric acid & $\begin{array}{l}\text { Less corrosion of production equipment } \\
\text { Reuse of the } \mathrm{H}_{2} \mathrm{SO}_{4} \text { waste } \\
\text { Can use titanium low grade ilmenite } \\
\text { Low capital cost } \\
\text { Low energy consumption }\end{array}$ & $\begin{array}{l}\text { Require high acid concentration } \\
\text { Less efficient in removing impurities } \\
\text { Abundant generation of acid and solid waste } \\
\text { Difficulty in treatment of Iron(II) sulfate and waste acid }\end{array}$ & {$[62,90,93-95]$} \\
\hline Weak acid digestion & $\begin{array}{l}\text { Requires low acid concentration } \\
\text { Selectivity for Ti is higher over Fe } \\
\text { Less corrosion }\end{array}$ & $\begin{array}{l}\text { High energy consumption } \\
\text { High cost }\end{array}$ & [88] \\
\hline Alkaline digestion & Selectivity for Ti is higher over $\mathrm{Fe}$ & $\begin{array}{l}\text { Requires acid to transform of titanate to } \mathrm{TiO}_{2} \\
\text { Requires high alkaline concentration } \\
\text { High energy consumption }\end{array}$ & {$[96]$} \\
\hline $\begin{array}{l}\text { Ammonium chlo- } \\
\text { ride salt digestion }\end{array}$ & $\begin{array}{l}\text { Isolation synthetic rutile } \\
\text { Isolate iron powder }\end{array}$ & $\begin{array}{l}\text { Requirement of oxygen } \\
\text { High energy consumption }\end{array}$ & [82-84] \\
\hline
\end{tabular}


been reported so far opening new avenues to research in this area. However, heterostructures have been prepared by using natural ilmenite as the raw material and the solution resulted after digestion as the precursor. Thambiliyagodage et al. report the synthesis of binary $\mathrm{Fe}_{2} \mathrm{TiO}_{5} / \mathrm{TiO}_{2}$ nanocomposites using only the precursor generated after the digestion of ilmenite [106] and ternary $\mathrm{Fe}_{2} \mathrm{O}_{3} / \mathrm{Fe}_{2} \mathrm{TiO}_{5} / \mathrm{TiO}_{2}$ composite using the precursor and externally added iron [107], and they have shown high photocatalytic activity on degradation of methylene blue under sunlight. The rate of photodegradation of methylene blue under sunlight $\left(0.038 \mathrm{~min}^{-1}\right)$ in the presence of $2 \mathrm{~g} / \mathrm{L}, \mathrm{Fe}_{2} \mathrm{O}_{3} / \mathrm{Fe}_{2} \mathrm{TiO}_{5} / \mathrm{TiO}_{2}$ is greater than the rate of photodegradation of methylene blue $\left(0.028 \mathrm{~min}^{-1}\right)$ under $300 \mathrm{~W}$ simulated sunlight in the presence of $1 \mathrm{~g} / \mathrm{L}$ of the same ternary heterostructure synthesized by Iron nitrate, tetrabutyl titanate and hexamethylenetetramine [108]. The reason cannot be directly attributed to the difference in the dosage of the catalyst as Thambiliyagodage et al. have used normal scattered sunlight, while Bhoi et al. used simulated sunlight. Nanoflower like $\mathrm{Fe}_{2} \mathrm{TiO}_{5} / \mathrm{TiO}_{2}$ was obtained by treating ilmenite in $\mathrm{NaOH}$ hydrothermally by Fernando et al. and have been used for electrocatalytic $\mathrm{H}_{2}$ evolution [109]. Multi-shelled $\mathrm{TiO}_{2} / \mathrm{Fe}_{2} \mathrm{TiO}_{5}$ synthesized using $\mathrm{TiCl}_{4}$ and $\mathrm{FeCl}_{3}$ have shown to be effective in water oxidation under solar light [110]. Further, magnetic properties of $\mathrm{Fe}_{2} \mathrm{TiO}_{5}$ synthesized by natural ilmenite via co-precipitation method [111] and via oxidation [112] have been also studied. Activities of the composites synthesized from natural ilmenite and synthetic chemicals are not compared in this review as different conditions have been used by different researchers. Research projects should be elaborated in finding the potential new applications of products prepared by using ilmenite as the raw material. Leachates obtained from the dissolution of ilmenite should be chemically treated to produce more titanium derived products. Leachates could be treated in different methods including sol gel synthesis, spray pyrolysis, electrochemical deposition, hydrothermal synthesis etc. to produce nanomaterials with different morphologies that could have different properties which can be applied to various applications. Further, obtained leachate could be combined with other chemicals such as $\mathrm{CuCl}_{2}, \mathrm{ZnCl}_{2}, \mathrm{FeCl}_{3}$ to produce heterojunctions which could be used as visible active photocatalysts to degrade organic pollutants. However, given that ilmenite is a natural material available for low cost, converting it to a titanium precursor consumes a high amount of chemicals and energy. Chemicals like acids, bases and salts were supposed to use in very high concentrations. Further, as ilmenite is a macro material dissolution is less efficient. Therefore, techniques like milling have been used to reduce the particle size and further, to change the chemical composition to facilitate digestion. However, milling requires high temperatures and the instrument which add more depth to the cost of the process. Considering the above, it is evident that there is more space for innovative research in the field discussed in this review.

\section{Conclusions}

Ilmenite partially dissolves in strong acids such as hydrochloric acid, sulfuric acid and weak acids including oxalic acid, phosphoric acid, citric acid to yield titanium and iron in the leachate. Generally, with increasing acid concentration, leaching time and leaching temperatures dissolution of ilmenite has increased. Addition of a reducing agent such as Fe increases the dissolution of ilmenite, and pseudobrookite phase formed during the oxidation of ilmenite resulting in a higher titanium yield. Formation of the pesudobrookite phase is prevented when $\mathrm{Na}_{2} \mathrm{~S}, \mathrm{ZnO}$ and $\mathrm{ZnS}$ are added in the preoxidation increasing the yield of titanium and iron from acid leaching. Leaching of ilmenite in potassium hydroxide would produce potassium titanate which may need additional acid treatment step to enhance the further dissolution. Leachates obtained from digestion of ilmenite has been used as a precursor to synthesize $\mathrm{TiO}_{2}$, while the residue obtained after the treatment were also rich with $\mathrm{TiO}_{2}$. Therefore, natural ilmenite can be used to produce $\mathrm{TiO}_{2}$ which is an effective white colour pigment and $\mathrm{TiO}_{2}$ based nanomaterials that are efficient photocatalysts for generation of energy via water splitting and degradation of organic pollutants in wastewater.

Acknowledgements This research was supported by the Accelerating Higher Education Expansion and Development (AHEAD) Operation of the Ministry of Higher Education funded by the World Bank.

Authors' contributions CT conceived the idea, designed the project, gathered data from all the sources, acquired funds, wrote the first draft of the manuscript and edited the manuscript with RW and MB. RW and MB contributed immensely on editing the manuscript. RW and MB contributed to acquire funds. All authors read and approved the final manuscript.

Funding This research was supported by the Accelerating Higher Education Expansion and Development (AHEAD) Operation of the Ministry of Higher Education funded by the World Bank. 


\section{Declarations}

Competing interests The authors report no conflict of interest.

Open Access This article is licensed under a Creative Commons Attribution 4.0 International License, which permits use, sharing, adaptation, distribution and reproduction in any medium or format, as long as you give appropriate credit to the original author(s) and the source, provide a link to the Creative Commons licence, and indicate if changes were made. The images or other third party material in this article are included in the article's Creative Commons licence, unless indicated otherwise in a credit line to the material. If material is not included in the article's Creative Commons licence and your intended use is not permitted by statutory regulation or exceeds the permitted use, you will need to obtain permission directly from the copyright holder. To view a copy of this licence, visit http://creativecommons.org/licenses/by/4.0/.

\section{References}

1. Miyoshi A, Nishioka S, Maeda K. Water splitting on rutile TiO2-based photocatalysts. Chem A Eur J. 2018;24(69):18204-19. https:// doi.org/10.1002/chem.201800799.

2. Wolcott A, Smith WA, Kuykendall TR, Zhao Y, Zhang JZ. Photoelectrochemical water splitting using dense and aligned TiO 2 nanorod arrays. Small. 2009;5(1):104-11. https://doi.org/10.1002/smll.200800902.

3. Cowan AJ, Tang J, Leng W, Durrant JR, Klug DR. Water splitting by nanocrystalline TiO 2 in a complete photoelectrochemical cell exhibits efficiencies limited by charge recombination. J Phys Chem C. 2010;114(9):4208-14. https://doi.org/10.1021/jp909993w.

4. Haque MM, Muneer M. TiO2-mediated photocatalytic degradation of a textile dye derivative, bromothymol blue, in aqueous suspensions. Dye Pigment. 2007;75(2):443-8. https://doi.org/10.1016/j.dyepig.2006.06.043.

5. Neppolian B, Choi HC, Sakthivel S, Arabindoo B, Murugesan V. Solar light induced and TiO2 assisted degradation of textile dye reactive blue 4. Chemosphere. 2002;46(8):1173-81. https://doi.org/10.1016/S0045-6535(01)00284-3.

6. Poulios I, Aetopoulou I. Photocatalytic degradation of the textile dye reactive orange 16 in the presence of tio 2 suspensions. Environ Technol (United Kingdom). 1999;20(5):479-87. https://doi.org/10.1080/09593332008616843.

7. Mengyue Z, Shifu C, Yaowu T. Photocatalytic degradation of organophosphorus pesticides using thin films of TiO2. J Chem Technol Biotechnol. 1995;64(4):339-44. https://doi.org/10.1002/jctb.280640405.

8. Zhu X, Yuan C, Bao Y, Yang J, Wu Y. Photocatalytic degradation of pesticide pyridaben on TiO2 particles. J Mol Catal A Chem. 2005;229(1-2):95-105. https://doi.org/10.1016/j.molcata.2004.11.010.

9. Sarkar S, Chakraborty S, Bhattacharjee C. Photocatalytic degradation of pharmaceutical wastes by alginate supported TiO2 nanoparticles in packed bed photo reactor (PBPR). Ecotoxicol Environ Saf. 2015;121:263-70. https://doi.org/10.1016/j.ecoenv.2015.02. 035.

10. He Y, Sutton NB, Rijnaarts HHH, Langenhoff AAM. Degradation of pharmaceuticals in wastewater using immobilized TiO2 photocatalysis under simulated solar irradiation. Appl Catal B Environ. 2016;182:132-41. https://doi.org/10.1016/j.apcatb.2015.09.015.

11. Yang H, Li G, An T, Gao Y, Fu J. Photocatalytic degradation kinetics and mechanism of environmental pharmaceuticals in aqueous suspension of TiO2: A case of sulfa drugs. Catal Today. 2010;153(3-4):200-7. https://doi.org/10.1016/j.cattod.2010.02.068.

12. Kubacka A, et al. Boosting TiO2-anatase antimicrobial activity: Polymer-oxide thin films. Appl Catal B Environ. 2009;89(3-4):441-7. https://doi.org/10.1016/j.apcatb.2009.01.002.

13. Kubacka A, et al. Understanding the antimicrobial mechanism of TiO 2 -based nanocomposite films in a pathogenic bacterium. Sci Rep. 2014;4(1):1-9. https://doi.org/10.1038/srep04134.

14. Mohamed HH, Hammami I, Baghdadi HA, Al-Jameel SS. Multifunctional tio2 microspheres-rgo as highly active visible light photocatalyst and antimicrobial agent. Mater Express. 2018;8(4):345-52. https://doi.org/10.1166/mex.2018.1437.

15. Ko KH, Lee YC, Jung YJ. Enhanced efficiency of dye-sensitized TiO2 solar cells (DSSC) by doping of metal ions. J Colloid Interface Sci. 2005;283(2):482-7. https://doi.org/10.1016/j.jcis.2004.09.009.

16. Bhogaita M, Yadav S, Bhanushali AU, Parsola AA, Pratibha Nalini R. Synthesis and characterization of TiO2 thin films for DSSC prototype. Materials Today. 2016;3(6):2052-61. https://doi.org/10.1016/j.matpr.2016.04.108.

17. Ali I, Suhail M, Alothman ZA, Alwarthan A. "Recent advances in syntheses, properties and applications of TiO2 nanostructures", RSC Advances, 8: 53. R Soc Chem. 2018;30125-30147:24. https://doi.org/10.1039/c8ra06517a.

18. Song T, Paik U. "TiO2 as an active or supplemental material for lithium batteries. J Mater Chem A. 2015;14-31:15. https://doi.org/10. $1039 / \mathrm{c} 5 \mathrm{ta0} 0688 \mathrm{f}$.

19. El-Deen SS, et al. Anatase TiO2 nanoparticles for lithium-ion batteries. Ionics (Kiel). 2018;24(10):2925-34. https://doi.org/10.1007/ s11581-017-2425-y.

20. Braun JH, Baidins A, Marganski RE. TiO2 pigment technology: a review. Prog Org Coatings. 1992;20(2):105-38. https://doi.org/10. 1016/0033-0655(92)80001-D.

21. Umebayashi T, Yamaki T, Itoh H, Asai K. Analysis of electronic structures of $3 \mathrm{~d}$ transition metal-doped TiO2 based on band calculations. J Phys Chem Solids. 2002;63(10):1909-20. https://doi.org/10.1016/S0022-3697(02)00177-4.

22. Basavarajappa PS, Patil SB, Ganganagappa N, Reddy KR, Raghu AV, Reddy CV. Recent progress in metal-doped TiO2, non-metal doped/codoped TiO2 and TiO2 nanostructured hybrids for enhanced photocatalysis. Int J Hydrogen Energy. 2020;45(13):7764-78. https://doi.org/10.1016/j.ijhydene.2019.07.241.

23. Vinodgopal K, Kamat PV. Enhanced rates of photocatalytic degradation of an azo dye using SnO2/TiO2 coupled semiconductor thin films. Environ Sci Technol. 1995;29(3):841-5. https://doi.org/10.1021/es00003a037.

24. Xiang C, Li M, Zhi M, Manivannan A, Wu N. Reduced graphene oxide/titanium dioxide composites for supercapacitor electrodes: Shape and coupling effects. J Mater Chem. 2012;22(36):19161-7. https://doi.org/10.1039/c2jm33177b. 
25. Shao F, Sun J, Gao L, Chen J, Yang S. Electrophoretic deposition of TiO2 nanorods for low-temperature dye-sensitized solar cells. RSC Adv. 2014;4(15):7805-10. https://doi.org/10.1039/C3RA47286H.

26. Dundar I, Krichevskaya M, Katerski A, Acik IO. TiO2 thin films by ultrasonic spray pyrolysis as photocatalytic material for air purification. R Soc Open Sci. 2019;6:2. https://doi.org/10.1098/RSOS.181578.

27. Arami H, Mazloumi M, Khalifehzadeh R, Sadrnezhaad SK. Sonochemical preparation of TiO2 nanoparticles. Mater Lett. 2007;61(2324):4559-61. https://doi.org/10.1016/J.MATLET.2007.02.051.

28. Falk GS, Borlaf M, López-Muñoz MJ, Fariñas JC, Rodrigues-Neto JB, Moreno R. Microwave-assisted synthesis of TiO2 nanoparticles: photocatalytic activity of powders and thin films. J Nanoparticle Res. 2018;202(20):1-10. https://doi.org/10.1007/S11051-018-4140-7.

29. Kang OL, Ahmad A, Rana UA, Hassan NH. Sol-gel titanium dioxide nanoparticles: preparation and structural characterization. J Nanotechnol. 2016. https://doi.org/10.1155/2016/5375939.

30. Nkele AC, et al. A study on titanium dioxide nanoparticles synthesized from titanium isopropoxide under SILAR-induced gel method: Transition from anatase to rutile structure. Inorg Chem Commun. 2020;112:107705. https://doi.org/10.1016/J.INOCHE.2019.107705.

31. Darvishi M, Seyed-Yazdi J. Characterization and comparison of photocatalytic activities of prepared TiO2/graphene nanocomposites using titanium butoxide and TiO2 via microwave irradiation method. Mater Res Express. 2016;3(8):085601. https://doi.org/10.1088/ 2053-1591/3/8/085601.

32. Shi W, Park AH, Xu S, Yoo PJ, Kwon YU. Continuous and conformal thin TiO2-coating on carbon support makes Pd nanoparticles highly efficient and durable electrocatalyst. Appl Catal B Environ. 2021;284: 119715. https://doi.org/10.1016/J.APCATB.2020.119715.

33. Watanabe N, Kaneko T, Uchimaru Y, Yanagida S, Yasumori A, Sugahara Y. Preparation of water-dispersible TiO2 nanoparticles from titanium tetrachloride using urea hydrogen peroxide as an oxygen donor. CrystEngComm. 2013;15(48):10533-40. https://doi.org/ 10.1039/C3CE41561A.

34. Thambiliyagodage C. Activity enhanced $\mathrm{TiO} 2$ nanomaterials for photodegradation of dyes - A review. Environ Nanotechnol Monit Manag. 2021;16:100592. https://doi.org/10.1016/J.ENMM.2021.100592.

35. Kothari NC. Recent developments in processing ilmenite for titanium. Int J Miner Process. 1974;1(4):287-305. https://doi.org/10. 1016/0301-7516(74)90001-5.

36. Nguyen TH, Lee MS. A review on the recovery of titanium dioxide from ilmenite ores by direct leaching technologies. Mineral Process Extract Metal Rev. 2019;40(4):231-47. https://doi.org/10.1080/08827508.2018.1502668.

37. Haverkamp RG, Kruger D, Rajashekar R. The digestion of New Zealand ilmenite by hydrochloric acid. Hydrometallurgy. 2016;163:198203. https://doi.org/10.1016/j.hydromet.2016.04.015.

38. Zhang W, Zhu Z, Cheng CY. A literature review of titanium metallurgical processes. Hydrometallurgy. 2011;108(3-4):177-88. https:// doi.org/10.1016/j.hydromet.2011.04.005.

39. Schulz KJ, DeYoung JH, Seal RR, Bradley DC. Critical mineral resources of the United States: economic and environmental geology and prospects for future supply. Geol Surv, 2018.

40. "•Titanium production worldwide by country 2020 | Statista." https://www.statista.com/statistics/759972/mine-production-titan ium-minerals-worldwide-by-country/. Accessed 28, 2021.

41. Mahmoud MHH, Afifi AAI, Ibrahim IA. Reductive leaching of ilmenite ore in hydrochloric acid for preparation of synthetic rutile. Hydrometallurgy. 2004;73(1-2):99-109. https://doi.org/10.1016/j.hydromet.2003.08.001.

42. Shahien MG, Khedr MMH, Maurice AE, Farghali AA, Ali RAM. Synthesis of high purity rutile nanoparticles from medium-grade Egyptian natural ilmenite. Beni-Suef Univ J Basic Appl Sci. 2015;4(3):207-13. https://doi.org/10.1016/j.bjbas.2015.05.013.

43. Ramadan AM, Farghaly M, Fathy WM, Ahmed MM. Leaching and kinetics studies on processing of Abu-Ghalaga ilmenite ore. 2016.

44. Wahyuningsih S, Rinawati L, Munifa RMI, Ramelan AH, Sulistyono E. TiO2Nanorods preparation from titanyl sulphate produced by dissolution of ilmenite. IOP Conf Ser Mater Sci Eng. 2017;176:012042. https://doi.org/10.1088/1757-899x/176/1/012042.

45. Lalasari LH, Yuwono AH, Firdiyono F, Rochman NT, Harjanto S, Suharno B. Controlling the nanostructural characteristics of TiO2 nanoparticles derived from ilmenite mineral of Bangka island through sulfuric acid route. Appl Mech Mater. 2013;391:34-40. https:// doi.org/10.4028/www.scientific.net/AMM.391.34.

46. S. Mohammad Ali, "Production of Nanosized Synthetic Rutile from Ilmenite Concentrate by Sonochemical HCl and H 2 SO 4 Leaching," Iranian Institute of Research and Development in Chemical Industries (IRDCI)-ACECR, 2014. Accessed: 30, 2020. http://www. ijcce.ac.ir/article_10749.html.

47. Palliyaguru L, Arachchi NDH, Jayaweera CD, Jayaweera PM. Production of synthetic rutile from ilmenite via anion-exchange. Miner Process Extr Metall Trans Inst Min Metall. 2018;127(3):169-75. https://doi.org/10.1080/03719553.2017.1331621.

48. Arachchi NDH, Peiris GS, Shimomura M, Jayaweera PM. Decomposition of ilmenite by ZnO/ZnS: enhanced leaching in acid solutions. Hydrometallurgy. 2016;166:73-9. https://doi.org/10.1016/j.hydromet.2016.09.001.

49. Welham NJ. A parametric study of the mechanically activated carbothermic reduction of ilmenite. Miner Eng. 1996;9(12):1189-200. https://doi.org/10.1016/S0892-6875(96)00115-X.

50. Chen Y. Different oxidation reactions of ilmenite induced by high energy ball milling. J Alloys Compd. 1998;266(1-2):150-4. https:// doi.org/10.1016/S0925-8388(97)00494-5.

51. Tao T, Chen Y. Direct synthesis of rutile TiO2 nanorods with improved electrochemical lithium ion storage properties. Mater Lett. 2013;98:112-5. https://doi.org/10.1016/j.matlet.2013.01.132.

52. Li C, Liang B, Chen SP. Combined milling-dissolution of Panzhihua ilmenite in sulfuric acid. Hydrometallurgy. 2006;82(1-2):93-9. https://doi.org/10.1016/j.hydromet.2006.04.001.

53. Song B, Zhang B, Xi F, Lv X, Carbothermic reduction of ilmenite concentrate with coke assisted by high energy ball milling. In: TMS Annual Meeting, 2014, 563-571, doi: https://doi.org/10.1007/978-3-319-48234-7_56.

54. Wu F, et al. Hydrogen peroxide leaching of hydrolyzed titania residue prepared from mechanically activated Panzhihua ilmenite leached by hydrochloric acid. Int J Miner Process. 2011;98(1-2):106-12. https://doi.org/10.1016/j.minpro.2010.10.013.

55. Sasikumar C, Rao DS, Srikanth S, Mukhopadhyay NK, Mehrotra SP. Dissolution studies of mechanically activated Manavalakurichi ilmenite with $\mathrm{HCl}$ and H2SO4. Hydrometallurgy. 2007;88(1-4):154-69. https://doi.org/10.1016/j.hydromet.2007.03.013. 
56. Sasikumar C, Rao DS, Srikanth S, Ravikumar B, Mukhopadhyay NK, Mehrotra SP. Effect of mechanical activation on the kinetics of sulfuric acid leaching of beach sand ilmenite from Orissa, india. Hydrometallurgy. 2004;75(1-4):189-204. https://doi.org/10.1016/j. hydromet.2004.08.001.

57. Jayaweera PM, Jayaweera PVV, Jayasundara UL, Jayaweera CD, Peiris GS, Premalal EVA. Photo induced reductive leaching of iron from ilmenite in hydrochloric acid solutions. Trans Institutions Min Metall Sect C Miner Process Extr Metall. 2011;120(3):191-6. https:// doi.org/10.1179/1743285511Y.0000000018.

58. Han KN, Rubcumintara T, Fuerstenau MC. Leaching behavior of ilmenite with sulfuric acid. Metall Trans B. 1987;18(2):325-30. https:// doi.org/10.1007/BF02656150.

59. Xiong X, Wang Z, Wu F, Li X, Guo H. Preparation of TiO2 from ilmenite using sulfuric acid decomposition of the titania residue combined with separation of Fe3+ with EDTA during hydrolysis. Adv Powder Technol. 2013;24(1):60-7. https://doi.org/10.1016/j.apt. 2012.02.002.

60. Li Z, Wang Z, Li G. Preparation of nano-titanium dioxide from ilmenite using sulfuric acid-decomposition by liquid phase method. Powder Technol. 2016;287:256-63. https://doi.org/10.1016/j.powtec.2015.09.008.

61. Latifa H, Yuwono AH, Firdiyono F, Rochman NT, Harjanto S, Suharno B. Controlling the Nanostructural Characteristics of TiO2 Nanoparticles Derived from Ilmenite Mineral of Bangka Island through Sulfuric Acid Route. Appl Mech Mater. 2013;391:34-40. https://doi.org/ 10.4028/www.scientific.net/AMM.391.34.

62. Jia L, et al. Beneficiation of titania by sulfuric acid pressure leaching of Panzhihua ilmenite. Hydrometallurgy. 2014;150:92-8. https://doi. org/10.1016/j.hydromet.2014.09.016.

63. Torres-Luna JA, Sanabria NR, Carriazo JG. Powders of iron(III)-doped titanium dioxide obtained by direct way from a natural ilmenite. Powder Technol. 2016;302:254-60. https://doi.org/10.1016/j.powtec.2016.08.056.

64. Wahyuningsih S, et al. The Effects of Leaching Process to the TiO2Synthesis from Bangka IImenite. IOP Conf Ser Mater Sci Eng. 2018;333: 012049. https://doi.org/10.1088/1757-899x/333/1/012049.

65. Wahyuningsih S, Ramelan AH, Munifa RMI, Saputri LNMZ, Chasanah U. Synthesis of TiO2nanorods from titania and titanyl sulfate produced from ilmenite dissolution by hydrothermal method. J Phys Conf Ser. 2016;776: 012044. https://doi.org/10.1088/1742-6596/776/1/ 012044.

66. Wahyuningsih S, et al. Decomposition of ilmenite in hydrochloric acid to obtain high grade titanium dioxide. Asian $\mathrm{J}$ Chem. 2013;25(12):6791-4. https://doi.org/10.14233/ajchem.2013.14692.

67. Gupta SK, Rajakumar V, Grieveson P. Phase transformations during heating of Ilmenite concentrates. Metall Trans B. 1991;22(5):711-6. https://doi.org/10.1007/BF02679027.

68. Vásquez R, Molinaaa A, Leachinggoffilmeniteeanddpre-oxidizeddilmeniteeinn hydrochloriccaciddtooobtainnhighhgradeetitaniumm dioxidee, 2008.

69. Claassen JO, Meyer EHO, Rennie J, Sandenbergh RF. Iron precipitation from zinc-rich solutions: Defining the Zincor Process. Hydrometallurgy. 2002;67(1-3):87-108. https://doi.org/10.1016/S0304-386X(02)00141-X.

70. Jha MK, Kumar V, Singh RJ. Review of hydrometallurgical recovery of zinc from industrial wastes. Resour Conserv Recycl. $2001 ; 33(1): 1-22$. https://doi.org/10.1016/S0921-3449(00)00095-1.

71. Baba AA, Adekola FA. Beneficiation of a Nigerian sphalerite mineral: Solvent extraction of zinc by Cyanex 272 in hydrochloric acid. Hydrometallurgy. 2011;109(3-4):187-93. https://doi.org/10.1016/j.hydromet.2011.06.004.

72. Palliyaguru L, Kulathunga MSU, Kumarasinghe KGRU, Jayaweera CD, Jayaweera PM. Facile synthesis of titanium phosphates from ilmenite mineral sand: Potential white pigments for cosmetic applications. J Cosmet Sci. 2019;70(3):149-59.

73. Senzui M, Tamura T, Miura K, Ikarashi Y, Watanabe Y, Fujii M. Study on penetration of titanium dioxide (TiO2) nanoparticles into intact and damaged skin in vitro. J Toxicol Sci. 2010;35(1):107-13. https://doi.org/10.2131/jts.35.107.

74. Purnamawati S, Indrastuti N, Danarti R, Saefudin T. “The role of moisturizers in addressing various kinds of dermatitis: A review”, Clinical Medicine and Research, 15: 3-4. Marshfield Clinic. 2017;75-87:01. https://doi.org/10.3121/cmr.2017.1363.

75. Palliyaguru L, Kulathunga US, Jayarathna LI, Jayaweera CD, Jayaweera PM. A simple and novel synthetic route to prepare anatase TiO2 nanopowders from natural ilmenite via the H3PO4/NH3 process. Int J Miner Metall Mater. 2020;27(6):846-55. https://doi.org/10.1007/ s12613-020-2030-3.

76. Jonglertjunya W, Rubcumintara T. Titanium and iron dissolutions from ilmenite by acid leaching and microbiological oxidation techniques. Asia-Pacific J Chem Eng. 2013;8(3):323-30. https://doi.org/10.1002/apj.1663.

77. Nayl AA, Aly HF. Acid leaching of ilmenite decomposed by KOH. Hydrometallurgy. 2009;97(1-2):86-93. https://doi.org/10.1016/j.hydro met.2009.01.011.

78. Liu Y, Qi T, Chu J, Tong Q, Zhang Y. Decomposition of ilmenite by concentrated KOH solution under atmospheric pressure. Int J Miner Process. 2006;81(2):79-84. https://doi.org/10.1016/j.minpro.2006.07.003.

79. Liu YM, Lü H, Qi T, Zhang Y. Extraction behaviours of titanium and other impurities in the decomposition process of ilmenite by highly concentrated KOH solution. Int J Miner Metall Mater. 2012;19(1):9-14. https://doi.org/10.1007/s12613-012-0508-3.

80. Kordzadeh-Kermani V, Schaffie M, Hashemipour Rafsanjani H, Ranjbar M. A modified process for leaching of ilmenite and production of TiO2 nanoparticles. Hydrometallurgy. 2020;198:105507. https://doi.org/10.1016/j.hydromet.2020.105507.

81. Epstein E. Mineral nutrition of plants: principles and perspectives. 1972.

82. Farrow JB, Ritchie IM, Mangano P. The reaction between reduced ilmenite and oxygen in ammonium chloride solutions. Hydrometallurgy. 1987;18(1):21-38. https://doi.org/10.1016/0304-386X(87)90014-4.

83. Zhao Q, Li M, Zhou L, Zheng M, Zhang T. Removal of Metallic Iron from Reduced IImenite by Aeration Leaching. Met. 2020;10(8):1020. https://doi.org/10.3390/MET10081020.

84. Ward J, Bailey S, Avraamides J. The use of ethylenediammonium chloride as an aeration catalyst in the removal of metallic iron from reduced ilmenite. Hydrometallurgy. 1999;53(3):215-32. https://doi.org/10.1016/S0304-386X(99)00046-8.

85. Tao T, et al. Ilmenite FeTiO3 nanoflowers and their pseudocapacitance. J Phys Chem C. 2011;115(35):17297-302. https://doi.org/10.1021/ jp203345s. 
86. Tao T, et al. Porous TiO2 with a controllable bimodal pore size distribution from natural ilmenite. CrystEngComm. 2011;13(5):1322-7. https://doi.org/10.1039/c0ce00533a.

87. Tao T, He L, Li J, Zhang Y. Large scale synthesis of TiO2-carbon nanocomposites using cheap raw materials as anode for lithium ion batteries. J Alloys Compd. 2014;615:1052-5. https://doi.org/10.1016/j.jallcom.2014.07.167.

88. Nayl AA, Awwad NS, Aly HF. Kinetics of acid leaching of ilmenite decomposed by KOH. Part 2. Leaching by H2SO4 and C2 $\mathrm{H} 2 \mathrm{O} 4$. J Hazard Mater. 2009;168(2-3):793-9. https://doi.org/10.1016/j.jhazmat.2009.02.076.

89. Welham NJ, Llewellyn DJ. Mechanical enhancement of the dissolution of ilmenite. Miner Eng. 1998;11(9):827-41. https://doi.org/10. 1016/S0892-6875(98)00070-3.

90. Middlemas S, Fang ZZ, Fan P. A new method for production of titanium dioxide pigment. Hydrometallurgy. 2013;131-132:107-13. https:// doi.org/10.1016/j.hydromet.2012.11.002.

91. Zhang L, Hu H, Liao Z, Chen Q, Tan J. Hydrochloric acid leaching behavior of different treated Panxi ilmenite concentrations. Hydrometallurgy. 2011;107(1-2):40-7. https://doi.org/10.1016/j.hydromet.2011.01.006.

92. Zhang L, Hu H, Wei L, Chen Q, Tan J. Hydrochloric acid leaching behaviour of mechanically activated Panxi ilmenite (FeTiO3). Purif Technol. 2010;73(2):173-8. https://doi.org/10.1016/j.seppur.2010.03.022.

93. Wu F, et al. Preparation of high-value TiO2 nanowires by leaching of hydrolyzed titania residue from natural ilmenite. Hydrometallurgy. 2013;140:82-8. https://doi.org/10.1016/j.hydromet.2013.09.003.

94. Tsuchida H, Narita E, Takeuchi H, Adachi M, Okabe T. Manufacture of High Pure Titanium(IV) Oxide by the Chloride Process. I. Kinetic Study on Leaching of Ilmenite Ore in Concentrated Hydrochloric Acid Solution. Bull Chem Soc Jpn. 1982;55(6):1934-8. https://doi.org/ 10.1246/bcsj.55.1934.

95. Zhang S, Nicol MJ. An electrochemical study of the reduction and dissolution of ilmenite in sulfuric acid solutions. Hydrometallurgy. 2009;97(3):146-52. https://doi.org/10.1016/j.hydromet.2009.02.009.

96. Zhang L, Li G, Zhang W. Synthesis of rutile from high titania slag by pyrometallurgical route. Trans Nonferrous Met Soc China. 2011;21(10):2317-22. https://doi.org/10.1016/S1003-6326(11)61014-5.

97. Thambiliyagodage C, Mirihana S. Photocatalytic activity of Fe and Cu co-doped TiO2 nanoparticles under visible light. J Sol-Gel Sci Technol. 2021;99(1):109-21. https://doi.org/10.1007/S10971-021-05556-4.

98. Yang XJ, Wang S, Sun HM, Wang XB, Lian JS. Preparation and photocatalytic performance of Cu-doped TiO2 nanoparticles. Trans Nonferrous Met Soc China. 2015;25(2):504-9. https://doi.org/10.1016/S1003-6326(15)63631-7.

99. Hajjaji A, et al. Photocatalytic activity of $\mathrm{Cr}$-doped TiO2 nanoparticles deposited on porous multicrystalline silicon films. Nanoscale Res Lett. 2014;9(1):1-6. https://doi.org/10.1186/1556-276X-9-543.

100. Deng QR, Xia XH, Guo ML, Gao Y, Shao G. Mn-doped TiO2 nanopowders with remarkable visible light photocatalytic activity. Mater Lett. 2011;65(13):2051-4. https://doi.org/10.1016/j.matlet.2011.04.010.

101. Ananpattarachai J, Kajitvichyanukul P, Seraphin S. Visible light absorption ability and photocatalytic oxidation activity of various interstitial N-doped TiO2 prepared from different nitrogen dopants. J Hazard Mater. 2009;168(1):253-61. https://doi.org/10.1016/j.jhazmat. 2009.02.036.

102. Matos J, et al. C-doped anatase TiO 2: Adsorption kinetics and photocatalytic degradation of methylene blue and phenol, and correlations with DFT estimations. J Colloid Interface Sci. 2019;547:14-29. https://doi.org/10.1016/j.jcis.2019.03.074.

103. Zhu M, et al. New method to synthesize S-doped TiO2 with stable and highly efficient photocatalytic performance under indoor sunlight irradiation. ACS Sustain Chem Eng. 2015;3(12):3123-9. https://doi.org/10.1021/acssuschemeng.5b01137.

104. Thambiliyagodage C, Usgodaarachchi L. Photocatalytic activity of N, Fe and Cu co-doped TiO2 nanoparticles under sunlight. Curr Res Green Sustain Chem. 2021;4: 100186. https://doi.org/10.1016/J.CRGSC.2021.100186.

105. Reda SM, Khairy M, Mousa MA. Photocatalytic activity of nitrogen and copper doped TiO2 nanoparticles prepared by microwave-assisted sol-gel process. Arab J Chem. 2020;13(1):86-95. https://doi.org/10.1016/J.ARABJC.2017.02.002.

106. Thambiliyagodage C, Mirihana S, Wijesekera R, Madusanka DS, Kandanapitiye M, Bakker M. Fabrication of Fe2TiO5/TiO2 binary nanocomposite from natural ilmenite and their photocatalytic activity under solar energy. Curr Res Green Sustain Chem. 2021;4: 100156. https://doi.org/10.1016/J.CRGSC.2021.100156.

107. Charitha T, Leshan U, Shanitha M, Ramanee W, Buddi L, Martin B. Efficient photodegradation activity of a-Fe2O3/Fe2TiO5/TiO2 and Fe2TiO5/TiO2 nanocomposites synthesized from natural ilmenite. Results Mater. 2021;12: 100219. https://doi.org/10.1016/J.RINMA. 2021.100219.

108. Bhoi YP, et al. Single step combustion synthesis of novel Fe2TiO5/a-Fe2O3/TiO2 ternary photocatalyst with combined double type-II cascade charge migration processes and efficient photocatalytic activity. Appl Surf Sci. 2020;525: 146571. https://doi.org/10.1016/j. apsusc.2020.146571.

109. Fernando N, et al. Pseudobrookite based heterostructures for efficient electrocatalytic hydrogen evolution. Mater Reports Energy. 2021;1(2):100020. https://doi.org/10.1016/J.MATRE.2021.100020.

110. Waqas $\mathrm{M}$, et al. Multi-shelled TiO2/Fe2TiO5 heterostructured hollow microspheres for enhanced solar water oxidation. Nano Res. 2017;10(11):3920-8. https://doi.org/10.1007/S12274-017-1606-3.

111. Mahmoud M, Hessien M, Alhadhrami A, Gobouri AA. Physicochemical properties of pseudobrookite Fe2TiO5 synthesized from ilmenite ore by co-precipitation route. Physicochem Probl Miner Process. 2019;55(1):290-300. https://doi.org/10.5277/PPMP18131.

112. Chen X, Deng J, Yu R, Chen J, Hu P, Xing X. A simple oxidation route to prepare pseudobrookite from panzhihua raw ilmenite. J Am Ceram Soc. 2010;93(10):2968-71. https://doi.org/10.1111/J.1551-2916.2010.03937.X.

Publisher's Note Springer Nature remains neutral with regard to jurisdictional claims in published maps and institutional affiliations. 